\title{
Warm temperatures, cool sponges: The effect of increased temperatures on the Antarctic sponge Isodictya sp
}

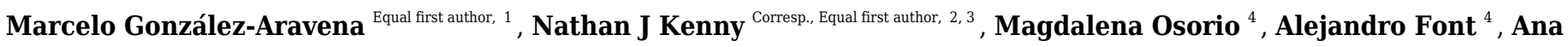 \\ Riesgo $^{2}$, César A Cárdenas ${ }^{\text {Corresp. } 1}$ \\ 1 Departamento Cientifico, Instituto Antártico Chileno, Puntas Arenas, Chile \\ Life Sciences, The Natural History Museum, London, London, United Kingdom \\ 3 Life Sciences, Oxford Brookes University, Oxford, United Kingdom \\ 4 Departamento Cientifico, Instituto Antartico Chileno, Puntas Arenas, Chile \\ Corresponding Authors: Nathan J Kenny, César A Cárdenas \\ Email address: nathanjameskenny@gmail.com, ccardenas@inach.cl
}

Although the cellular and molecular responses to exposure to relatively high temperatures (acute thermal stress or heat shock) have been studied previously, only sparse empirical evidence of how it affects cold-water species is available. As climate change becomes more pronounced in areas such as the Western Antarctic Peninsula, both long-term and occasional acute temperature rises will impact species found there, and it has become crucial to understand the capacity of these species to respond to such thermal stress.

Here we use the Antarctic sponge Isodictya sp. to investigate how sessile organisms (particularly Porifera) can adjust to acute short-term heat stress, by exposing this species to 3 and $5{ }^{\circ} \mathrm{C}$ for 4 hours, corresponding to predicted temperatures under high-end 2080 IPCC-SRES scenarios. Assembling a de novo reference transcriptome $(90,188$ contigs, $>93.7 \%$ metazoan BUSCO genes) we have begun to discern the molecular response employed by Isodictya to adjust to heat exposure.

Our initial analyses suggest that TGF- $\beta$, ubiquitin and hedgehog cascades are involved, alongside other genes. However, the degree and type of response changed little from 3 to $5{ }^{\circ} \mathrm{C}$ in the time frame examined, suggesting that even moderate rises in temperature could cause stress at the limits of this organism's capacity. Given the importance of sponges to Antarctic ecosystems, our findings are vital for discerning the consequences of short-term increases in Antarctic ocean temperature on these and other species. 
1

2

3

4

5

6

7

$8{ }^{1}$ Departamento Científico, Instituto Antártico Chileno, Plaza Muñoz Gamero 1055, Punta

9 Arenas, 6200965, Chile

$10{ }^{2}$ Life Sciences, The Natural History Museum, Cromwell Road, London SW7 5BD, UK

$11 \quad{ }^{3}$ Life Sciences, Oxford Brookes University, Oxford, United Kingdom

12

13

14

15

16

MGA: mgonzalez@inach.cl

17 NJK: nathanjameskenny@gmail.com

18

MO: magdalena.osorio.a@gmail.com

19 AF: afont@inach.cl

20 AR: a.riesgo@nhm.ac.uk

21 CAC: ccardenas@inach.cl

22

23 Corresponding author details:

24 NJK: +44 2079426475

25

CAC: +56612298124 
26

27

28

29

30

31

32

\section{Abstract}

Although the cellular and molecular responses to exposure to relatively high temperatures (acute thermal stress or heat shock) have been studied previously, only sparse empirical evidence of how it affects cold-water species is available. As climate change becomes more pronounced in areas such as the Western Antarctic Peninsula, both long-term and occasional acute temperature rises will impact species found there, and it has become crucial to understand the capacity of these species to respond to such thermal stress.

Here we use the Antarctic sponge /sodictya sp. to investigate how sessile organisms (particularly Porifera) can adjust to acute short-term heat stress, by exposing this species to 3 and $5{ }^{\circ} \mathrm{C}$ for 4 hours, corresponding to predicted temperatures under high-end 2080 IPCCSRES scenarios. Assembling a de novo reference transcriptome $(90,188$ contigs, $>93.7 \%$ metazoan BUSCO genes) we have begun to discern the molecular response employed by Isodictya to adjust to heat exposure.

Our initial analyses suggest that TGF- $\beta$, ubiquitin and hedgehog cascades are involved, alongside other genes. However, the degree and type of response changed little from 3 to $5{ }^{\circ} \mathrm{C}$ in the time frame examined, suggesting that even moderate rises in temperature could cause stress at the limits of this organism's capacity. Given the importance of sponges to Antarctic ecosystems, our findings are vital for discerning the consequences of short-term increases in Antarctic ocean temperature on these and other species. 
49

50

51

52

53

54

55

56

57

58

59

60

61

62

63

64

65

66

67

68

69

70

71

72

73

74

75

76

77

78

79

80

81

\section{Background}

.

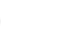

Sponges are vital components of a variety of ecosystems in terms of abundance and ecosystem services ${ }^{1,2}$. This is especially true in the Antarctic, where they are among the most common benthic species, providing habitat and food for a wide range of organisms $3,4,5,6$. Sponges, like most marine species, will be broadly, and perhaps adversely, affected by climate change, but at present studies into their capacity to cope with increases in temperature are limited in scope and number 7,8 .

The Western Antarctic Peninsula (WAP) is one of the areas of the planet which has experienced some of the most significant changes in air and water temperature ${ }^{9,10}$. Current estimates of climate change in the Antarctic suggest that the mean temperature of seawater could rise by about $0.6^{\circ} \mathrm{C}$ (Representative Concentration Pathway 2.6 ) to $2.0^{\circ} \mathrm{C}$ (Representative Concentration Pathway 8.5) (IPCC 2014)11. This is expected to have major implications for Antarctic organisms as they are highly sensitive to environmental variation ${ }^{12,13}$. For this reason the projected changes in water temperature constitutes a major threat to ecosystem function in these waters. Such changes would modify the prevalence of key functional species, thus affecting associated ecosystem processe ${ }^{14}$. However, we are only beginning to understand the resilience of many species found in the Antarctic to rising temperature conditions 12,15,16,17, and the point to which they will be affected by any changes in mean temperature, for either long or short periods of time. The deleterious effects of temperature exposure in sponges from other latitudes include bleaching of symbionts, tissue necrosis and death ${ }^{18}$. It is vital to gain this information in Antarctic sponge species, so that policy decisions can be made with a full understanding of the likely impacts of these changes.

Some sponge species have been suggested to be relatively robust to moderate changes in temperature. Caribbean and Brazilian coral-reef sponges have been investigated and found to survive fluctuations in ambient temperature ${ }^{19,20}$. A recent study, experimentally demonstrated that the boreal deep-sea sponge Geodia barretti is able to cope with temperature rises with few ill effects ${ }^{21}$. Other sponge species are however not so resilient $18,22,23$, and both reproduction ${ }^{24}$ and filtration ${ }^{25}$ in sponges has been shown to be affected by increases in temperature, even over short periods of time. In some cases, this has led to widespread mortality ${ }^{22,26}$.

We have little current understanding as to what makes some species able to cope with broad temperature ranges, and it is possible that Antarctic-dwelling species may be particularly vulnerable due to their specialisation for extremely cold, relatively stable temperature conditions $^{27}$. Their molecular components in particular may have altered over evolutionary time, 
82 as has been observed previously in a variety of species ${ }^{17}$, and warmer temperatures could 83 prove deleterious. The sponge /sodictya sp. (Fig 1A) is no exception to this. While this sponge is 84 commonly observed around the WAP and generally lives in waters with temperatures between $851.8{ }^{\circ} \mathrm{C}{ }^{28}$, it is rarely found in warmer areas, with summer peaks around the WAP reaching 1.5 $86{ }^{\circ} \mathrm{C}$ and $2{ }^{\circ} \mathrm{C}$ around Marguerite Bay and Palmer Archipelago respectively. Due to its ubiquity 87 and narrow normal temperature range, this sponge is an ideal model to test the consequences 88 of temperature exposure on cold-adapted species. Increasingly this sponge is exposed to 89 warmer summer temperatures across its natural range, with shallow-water temperatures 90 reaching $3^{\circ} \mathrm{C}$ in some places around the WAP29.

91 Illumina-based sequencing can reveal both subtle and broad changes in expression in 92 studies of model and non-model organisms ${ }^{30}$. These studies have the additional benefit of also 93 providing a suite of information on the gene sequences of the organism in question, which is 94 particularly useful for non-model species. While genomic-level datasets within the Porifera 95 remain depauperate and limit our understanding of adaptation to particular conditions, a number of investigations into the transcriptomic complements of a variety of sponges have now been successfully performed $31,32,33$. The transcriptional changes in response to temperature shifts that occur within sponges themselves ${ }^{23,34}$ and changes in their bacterial symbionts ${ }^{18,35,36,37.38}$ have also only recently begun to be unveiled. Some changes in gene expression revealed by these studies, such as those in HSP70 expression ${ }^{34,39}$ are easily explained with reference to known metazoan responses to temperature fluctuation and heat shock. Similarly, responses such as the up-regulation of genes involved in signal transduction, tissue morphogenesis, cell signalling and antioxidant activity are all of clear utility to tissues as they adapt to thermal stresses. What has yet to be tested thoroughly is whether these changes are mirrored in extremophile species. It is possible that gene complements adapted to extremes may be less able to cope with heat shock, particularly over rapid time scales.

Our study demonstrates that some extremophile species such as Isodictya sp. may be able to respond to acute short term stress, but that there may be limits to the upper bounds of this response. Using a small number of replicates and two "heat shock" regimes, we have been able to use these findings to investigate the specific pathways used by these organisms, and contrast these with previous findings in species adapted to warmer temperature regimes. The sponge studied here, Isodictya sp. is one of the most common species in shallow-water rocky reefs (<25 m depth) around Doumer Island, Palmer Archipelago, WAP (Fig 1B).

In this manuscript we present the first transcriptomic analysis of the effect of acute warming on a cold-adapted sponge. Due to the constraints of working with polar species in 
116 Antarctic conditions the numbers of replicates is low, particularly for the control specimen. This

117 limits the strength of some of the conclusions that can be drawn from this work. Nevertheless,

118 given its novelty this knowledge will be vital for understanding the impact of temperature rises

119 on Antarctic species, but also for discrete, targeted investigation of the role of specific pathways

120 in temperature adaptation in the future.

121

122 Methods

123

124

Animal Collection and Heat Treatment

125

Adult samples of six individuals of the Antarctic sponge Isodictya sp. were collected by SCUBA diving at $10 \mathrm{~m}$ depth in Cape Kemp, off Yelcho Research Station, Doumer Island, WAP $\left(64^{\circ} 51^{\prime} \mathrm{S} 63^{\circ} 35^{\prime} \mathrm{W}\right.$, Fig $\left.1 \mathrm{~B}\right)$ in January 2017 . The study was conducted under permit $806 / 2015$ granted by the Chilean Antarctic Institute (INACH). Sponges were then transferred to the laboratory at Yelcho Station, where they were maintained in $140 \mathrm{~L}$ fiberglass tanks with unfiltered, flowing seawater (approximately $0.5{ }^{\circ} \mathrm{C}$, pumped directly from the sea floor near to collection site (5 -10 m depth)) for a week to allow acclimation to laboratory conditions. Tanks were covered with two layers of $1 \mathrm{~mm}$ shade cloth (fiberglass $50 \%$ neutral density screen) to represent light levels occurring in situ. Relative light intensity levels and temperature in the experimental tanks were measured (1 measurement every 15 minutes) during the duration of experiment with a HOBO Pendant ${ }^{\circledR}$ temperature/light data logger (Onset, USA). Sponges were then placed into one of three possible treatment conditions - a control tank, where samples were maintained in seawater pumped directly from the sea floor at approximately $0.5^{\circ} \mathrm{C}$, or one of two possible treatment temperatures, 3 and $5{ }^{\circ} \mathrm{C}$, with water warmed in a header tank before pumping into the treatment area, and subsequently maintained at a set temperature using SOBO Aquarium heaters (500 watt). These temperatures were chosen in line with empirical evidence of warming in the WAP ${ }^{29}$. Sponge samples were placed in individual treatment tanks, for a total of 3 treatments and two replicates $\left(2 x\right.$ control, $\left.2 x 3^{\circ} \mathrm{C}, 2 \times 5^{\circ} \mathrm{C}\right)$ although one control sample was not used for analysis as described in Results and Discussion.

\section{RNA Extraction and Sequencing}

Sponges were taken from tanks after 4 hours of exposure to the control/treatment conditions, and a single fragment of each sample, approx. $1 \mathrm{~cm}^{3}$, was taken immediately and placed in RNAlater (Qiagen) and stored at $-20{ }^{\circ} \mathrm{C}$ on site, before shipment on dry ice (with an 
150 Laboratorio de Biorrecursos at INACH, Punta Arenas. RNA was extracted from sponge samples 151 using E.Z.N.A Total RNA kit II (Omega Bio-Tek Inc.) according to the manufacturer's protocol 152 with a previous step of homogenization with liquid nitrogen. RNA quality and quantity was 153 determined on a 2100 Bioanalyser (Agilent Technologies). Quality control obtained an average 154 RIN value of 8.2. The sole sample with a RIN value less than 7 (a control sample, with RIN 6.2) 155 was not included in this work. $1 \mu \mathrm{g}$ of RNA from each sample was used to produce RNA 156 libraries for sequencing, with TruSeq Stranded mRNA kit (Illumina), 100bp nominal intra-read 157 fragment size, 15 rounds of amplification and adaptors AGTTCC, ATGTCA, CCGTCC, 158 GTCCGC and CGATGT.

159 Libraries were sequenced on a Hiseq2500 sequencer by the Macrogen provider, using 160 approximately one half of a run in total. The sequencing provider performed initial assessment 161 of read quality and de-multiplexing of reads according to their procedures, and provided us with 162 paired-end reads for download from an external server, with no unpaired orphan reads retained 163 by this process.

164

165

Quality Control and Assembly

We confirmed the removal of adapter sequences and overall sequence quality using the FastQC program ${ }^{40}$. Low-quality regions of reads were trimmed using Trimmomatic $0.33^{41}$ with 168 the following settings: ILLUMINACLIP.../Adaptors.fa:2:30:10 LEADING:3 TRAILING:3 SLIDINGWINDOW:4:20 MINLEN:30 where the Adaptors.fa file consisted of the appropriate indexes for the libraries in question. The resulting trimmed reads were then compressed using gzip and re-analysed with FastQC. Seqtk fqchk ${ }^{42}$ was used to determine average sequence quality scores.

Trimmed reads from all 5 samples were assembled into a reference transcriptome using Trinity version 2013_08_1443, with two non-standard settings: a minimum contig length of 200 bp and in silico read normalisation. Clustering of isoforms was performed natively by Trinity, but the assembly was not "flattened" to preserve isoformal and splice information for future work DeconSeq standalone version $0.4 .3^{44}$ was used to remove contamination, with settings -i 50 -c 50 , using pre-prepared bacterial, archean, hsref and viral databases (2,206, 155, 1 and 3,761 complete genomes respectively), resulting in our final reference assembly. This is available from the DOI and URL below as Supplementary File 1.

181 
183

184

185

186

187

188

189

190

191

192

193

194

195

196

197

198

199

200

201

202

203

204

205

206

207

208

209

210

211

212

214

215

216

28S and HSP70 sequences were extracted from our assemblies using BLASTN ${ }^{45}$ on a local server, using sequences of known orthology from Genbank as search queries. These were aligned to previously published sequences downloaded from the NCBI database using MAFFT 46. HSP70 gene alignments were cured using Gblocks ${ }^{47}$, although this was not necessary for the well-conserved $28 \mathrm{~S}$ sequence. Phylogenetic analysis was run in RAxML GUI ${ }^{48}$ using ML + Rapid Bootstrap, the GTR model (28S)/LG+I+G model (HSP70) and 1,000 bootstrap replicates. Phylogenetic and molecular evolutionary analyses of AIF genes were conducted using MEGA version $7.0^{49}$. The tree was inferred using the Neighbor-Joining method, based on the alignment of the sequences using ClustalW $2.0^{50}$ (alignment was improved using the Seaview software 4.6.551). Resultant tree topologies were evaluated by bootstrap analyses based on 1000 replicates.

\section{Transcriptome analysis and annotation}

To assess the content of the transcriptome BUSCO $\mathrm{v} 1.1 \mathrm{~b} 1^{52}$ was run against the reference transcriptome, using the eukaryotic and metazoan Basic Universal Single Copy Orthologue (BUSCO) gene lists to estimate completeness. Annotation of contigs was performed by translating the longest ORF for each contig using the getORF.py python script, taking the longest ORF, then using standalone BLASTP ${ }^{45}$ (cutoff $E$ value 0.000001 ) to search against the refseq protein database. This was supplemented using Blast2GO Pro53, where full InterPro scanning, mapping, annotation (including ANNEX) and enzyme code mapping was performed, the complete annotations for which are available as Supplementary File 2.

The KAAS-KEGG automatic annotation server was used to gain an understanding of the recovery of complete pathways in our transcriptome. These were generated using the online too $^{54}$ rather than as integrated into Blast2GO, due to the increased functionality of the standalone server. The bi-directional best hit method was used to identify and annotate the longest orfs from our contigs, with the protein sequences generated earlier used as the basis for these comparisons against a range of eukaryotic species. The maps generated by this were compared directly against extant ones previously generated for the sponge Amphimedon queenslandica, and the complete annotations are available as Supplementary File 3.

\section{Differential Expression Analysis and Over-representation Analysis}

14 Comparative analyses of gene expression were performed using RSEM ${ }^{55}$ as packaged within the Trinity ${ }^{43}$ module, using Bowtie ${ }^{56}$ for alignment. The three treatments (control, 3 and 5 ${ }^{\circ} \mathrm{C}$ ) had their replicates (1,2 and 2 respectively) cross-sample normalised according to Trimmed 
217 Mean of M-values. The three treatments were then cross-compared using edgeR ${ }^{57}$ within the 218 Trinity ${ }^{43}$ perl wrapper script, according to the "classic" pairwise model with a p-value cut off for 219 FDR of 0.0001 , a minimum absolute $(\log 2(a / b))$ change of 2 (i.e. 4 fold change) and a 220 dispersion setting of 0.1 , deliberately over-specified to preclude false positive identification of 221 over-expression. We excluded any differentially expressed contigs where transcription was only 222 detected in a single sample of any of the five used in this analysis, prior to clustering and any 223 further analysis or display, to avoid spurious results caused by transient expression or 224 contamination of single samples. As with the dispersion estimate, the $p$-value cutoff and 225 minimum absolute change values are stringent, to exclude potentially artifactual changes from 226 our analysis, given the small number of replicates. The remaining differentially-expressed gene 227 lists were then targeted for further analysis. These results are provided as Supplementary File 2284.

229 GO over-representation analysis was performed in Blast2GO Pro ${ }^{53}$ using Fisher's Exact 230 Test, with FDR control for multiple testing, with a p-value cutoff of $0.05^{58}$. The test sets were the 231 annotated results for the sequences present in each of the over-represented sets derived from 232 the differential expression analysis, analysed in turn, with the reference set the full list of 233 annotated contigs, minus those in the test set.

234

Results and Discussion

236

Sequencing and Read Cleaning

238

While 5 individual samples are noted here (a single control, and two replicates for both the $3{ }^{\circ} \mathrm{C}$ and $5{ }^{\circ} \mathrm{C}$ treatments) another control sample was also initially taken and sequencing performed as described above. Despite being morphologically identical, our initial assays of the sequences from that sample, and particularly the sequence of common molecular markers used 242 in phylogenetic comparison, including 28S rRNA and cytochrome c oxidase 1 (CO1) markers, 243 revealed that it is in fact a cryptic related species, which will be the subject of description in the 244 future (see Fig 1C). We have not included this sample in any of the analyses in this work. The 245 lack of a second control sample meant that comparisons of the treatment conditions limited 246 some conclusions, as discussed later in this manuscript.

247 Basic sequencing metrics can be seen in Table 1, alongside those after read cleaning. 248 Our initial FastQC analysis revealed the presence of low quality nucleotide sequence in the 249 second file of many pairs. Cleaning was therefore stringent, and resulted in markedly fewer, but 250 much better average quality, reads for all samples, which were then used for assembly of the 
251 reference transcriptome and for differential expression analysis. GC\% (which can be a crude 252 proxy for contamination or changes in expression) was even through all our samples, between 25344 and $46 \%$, and changed little with cleaning. A small number of over-represented sequences 254 were also initially observed in our reads, as is commonly observed in Illumina-based 255 transcriptomic analysis due to known biases in hexamer binding ${ }^{59}$. The difference in average 256 quality after cleaning was modest, with an average difference of around 2 in Phred score. Our 257 original reads have been uploaded to the NCBI SRA with accession number PRJNA415418.

258

259

260

261

262

263

264

265

266

267

268

269

270

271

272

273

274

275

276

277

278

279

280

281

282

283

284

\section{Assembly and Completeness}

Reads from all 5 samples were used to construct a reference assembly (Table 2), for use in further analysis (Supplementary File 1). We checked this for potential contamination using Deconseq, comparing our data to known bacterial, viral, 'archaea' ( $\mathrm{sensu}^{60}$, we are aware of archaean paraphyly) and human genomic sequences. With very permissive settings for recognition as foreign sequence (minimum thresholds for removal, $50 \%$ similarity across at least $50 \%$ of the contig length) 797 contigs were tagged as potential contamination. These were removed from our dataset before further analysis. It should be noted, however, that particularly novel bacterial sequences not yet represented in the $n r$ database may still be present in our data, despite the use of polyA sequencing, as these could not be represented in our removal database and therefore will not have been removed. While beyond the scope of this manuscript, changes in symbiont content may be vital for long-term adaptation to change.

Statistics related to our cleaned reference assembly can be seen in Table 2. A total of 90,188 contigs are present, and Trinity has automatically assigned 70,844 as independent "genes". A small amount of heterozygosity or potential splice variation has therefore been recognised, with 19,344 contigs flagged as isoformal variants of other contigs in our assembly. This is not unusual, and is in fact less than that recognised in some other de novo assemblies (for instance, ${ }^{61}$, where every gene possessed approximately 2 "isoform" variants on average). Our samples may therefore possess little in the way of genetic variability at most loci. Our reference assembly is well-assembled, with a high N50 (1,113 bp). 12,997 contigs were longer than this N50 value, and 14,633 longer than $1 \mathrm{~kb}$ in length.

To test the completeness of our transcriptomic dataset we used the BUSCO approach ${ }^{52}$, which revealed our dataset to be remarkably complete. Of 978 BUSCO orthogroups plausibly expected in any metazoan species, 916 complete BUSCOs were found (654 single copy, 262 duplicated, possibly reflecting allelic or isoform differences). 20 were present only as fragmentary sequence, while 42 were missing. Of the 303 eukaryotic BUSCO sequences, 298 
285 (98.4\%) were present, 213 as single copy, 85 with duplicates and 2 as fragmentary sequence. 286 Only 3 BUSCO groups were missing. By way of comparison, the published draft of the 287 Amphimedon queenslandica set is missing $1.6 \%$ of the eukaryote set (5 genes), and $4.9 \%$ (49) 288 of the metazoan complement ${ }^{33}$.

289

290

291

292

293

294

295

296

297

298

299

300

301

302

303

304

305

306

307

308

309

310

311

312

313

314

315

316

317

318

\section{Annotation and Content}

To annotate our data, we used automated methods, including the Blast2GOPro and KEGG platforms. Of 90,188 total contigs, 20,607 were given an initial annotation based on BLAST results vs. the Refseq database at an $E$ value cutoff of $10^{-6}$, chosen empirically to allow maximum annotation ability without introducing artifacts. Of these contigs, 7,303 had their "best hit" to proteins in the A. queenslandica genome. The diatoms Phaeodactylum tricornutum CCAP 1055/1 and Thalassiosira pseudonana CCMP1335 were observed as "best hit" species for 798 and 563 contigs respectively, which is not surprising as previous work as described abundant presence of diatoms in other Antarctic sponges 62,63. Annotated diatom data was not included in further analysis. No obvious bacterial, viral, human or archaeal contamination was observed, although as described earlier, 797 contigs were removed from our assembly by Deconseq before any further analysis.

More discrete annotation was then performed using Blast2GO Pro. Of the 20,607 contigs preliminarily annotated with Blast, 6,267 could not be annotated further. 1,389 were able to be "mapped" to GO terms, but were unable to be annotated further. 12,924 contigs received GO annotations (Supplementary File 2). 27 additional contigs had Interproscan results and were also placed into $\mathrm{GO}$ categories. While the expected total gene complement of a metazoan is often up to around twice this figure (e.g. Drosophila melanogaster has around 15,500, while humans contain around 20-25,000), our annotations are nonetheless a large proportion of the expected gene count of these sponges. This level of annotatable data is not unusual for de novo transcriptome assemblies, which will contain novel genes, fragments of complete genes, non coding RNA and UTR sequences alongside coding sequences. It should be noted that in even the most well-annotated genomes, not all genes can be placed in $\mathrm{GO}$ categories.

We also performed KEGG annotation on our de novo transcriptome using the KAASKEGG automatic annotation server, with its default BLAST settings, to understand the representation of key pathways in our transcriptomic datasets. The results of these annotations are provided in full as Supplementary File 3, but in general recovery was excellent with 37,313 genes annotated to existing KEGG terms. While sponges do not possess the full canonical complements of other metazoan phyla, as these were not present in the common ancestors of 
319 sponges and the broader Metazoa, we generally recover the expected gene complements of the 320 Porifera in our reference transcriptomic assembly, when mapped to the $A$, queenslandica KEGG 321 dataset. Together with BUSCO results and the raw number of annotated genes, this gives us 322 confidence in the depth of our transcriptomic resources.

323

324

325

326

327

328

329

330

331

332

333

334

335

336

337

338

339

340

341

342

343

344

345

346

347

348

349

350

351

352

\section{Differential Expression Results}

We utilised our samples to perform a differential expression analysis, aimed at discerning the specific genes up- and down-regulated by exposure to acute increased temperatures. It should be noted that due to experimental necessity, these are few in replicate number compared to many experiments, with $n=2$ at best. This limits the strength of conclusions that can be drawn particularly between control and treatment conditions, although treatment vs treatment comparisons are more robust. The sample correlation matrix and heatmap of relative expression for differentially expressed genes alone can be seen in Fig 2 . The large degree to which the 3 and $5{ }^{\circ} \mathrm{C}$ treatments resemble one another can be seen in the matrix in Fig $2 \mathrm{~A}$, where the 4 replicates show little differentiation from one another (black regions of matrix). Within-sample variation is observed (the long branches for each terminal node on the dendrogram) but little between-treatment variation is evident (see the small distances between nodes leading to the individual replicates). In Fig 2B, while some discreet inter-sample variation is observed, note the large downregulated quadrant of the matrix at bottom right, relative to high relative expression levels in the control sample at far left. Adding additional replicates would increase confidence in these results.

In general, we found a large number of genes whose expression was perturbed by heat treatment at both 3 and $5{ }^{\circ} \mathrm{C}$ (although please note this is in comparison to a single control sample). Between our control and $3{ }^{\circ} \mathrm{C}$ treatments, the transcriptional landscape changed considerably. Stringent criteria were applied for significance given the single control: cut off for FDR of 0.0001 , a min abs $(\log 2(a / b))$ change of 2 , but these results should be taken as indicative rather than quantitative. 1,435 contigs were noted to change in expression (767 upregulated, 668 downregulated at the $3{ }^{\circ} \mathrm{C}$ treatment compared to the control sample - again note this is a single control). This was mirrored in our control vs. $5{ }^{\circ} \mathrm{C}$ comparison, where 1,230 contigs changed significantly in expression (623 upregulated, 607 downregulated significantly at $5{ }^{\circ} \mathrm{C}$ compared to the single control sample). The complete list of differentially expressed genes and further details are given in Supplementary File 4. There was a large amount of overlap between these sets. In total, 322 genes were downregulated commonly in both the 3 and $5{ }^{\circ} \mathrm{C}$ samples when compared to the control. 383 genes were upregulated commonly in both the 3 and $5{ }^{\circ} \mathrm{C}$ 
353

354

355

356

357

358

359

360

361

362

363

364

365

366

367

368

369

370

371

372

373

374

375

376

377

378

379

380

381

382

383

384

385

386

samples compared to the control. These genes may be particularly interesting for further analysis, given their conserved role in thermal response, and we have provided these in Supplementary File 5. Contrastingly, genes that were not shared could provide specific information about responses at specific temperature points, and are also made available for further study. We re-iterate, however, that the single control sample means that these results are not as well-supported as our $3^{\circ} \mathrm{C}$ vs $5^{\circ} \mathrm{C}$ analysis.

The 20 most up and down regulated genes (and thus the ones with the highest statistical support, although vs a single control) in our control vs $3^{\circ} \mathrm{C}$ and control vs $5^{\circ} \mathrm{C}$ samples are of clear interest in understanding thermal stress response, and can be seen in Table 3. These contigs include those with similarity to heat shock proteins (heat shock 70 B2-like) and ribosomal proteins (40S ribosomal S13, 40S ribosomal S25), along with a large number of sequences with no clear homologues in the RefSeq database, and some of less clear utility (e.g. the Plant Cadmium Resistance 3-like family of eukaryote-conserved genes, although cadmium and these genes are noted to influence the HSP pathway ${ }^{64}$ ).

However, very few genes (5 upregulated in $5{ }^{\circ} \mathrm{C}$ sample vs $3{ }^{\circ} \mathrm{C}, 11$ downregulated) changed significantly in expression between the 3 and $5{ }^{\circ} \mathrm{C}$ treatment. This is a more reliable measurement than our control vs treatment comparisons, given the replicates for both of these samples. We speculate that this may be due to the transcriptional machinery of this sponge already operating at maximum capacity to adjust to thermal stress under the $3{ }^{\circ} \mathrm{C}$ treatment, with little extra ability to cope with changes brought by further increases in temperature, although longer exposure might also be needed to bring about more discrete transcriptional changes. Despite their small number, these genes are of a variety of annotations, including allograft inflammatory factor 1, ubiquitin carboxyl-terminal hydrolase isozyme L3-like and a FKBP6-like sequence, and could still be helping adjust to thermal stress at specific temperature ranges.

\section{GO over-representation analysis}

To gain a broad understanding of the nature of changes between our samples, we tested differentially expressed genes at given temperatures as our test sets, relative to our reference transcriptomes, and checked for over-representation of any gene categories using Fisher's Exact Test, correcting for false discovery rate and with a cutoff $p$ value of 0.05 , as integrated in Blast2GO. Our findings are based on the small number of replicates mentioned previously, but with a high stringency criteria for assigning significance. When we compared our control to our 3 and $5{ }^{\circ} \mathrm{C}$ samples a variety of statistically significant differences in contig 
387

388

389

390

391

392

393

394

395

396

397

398

399

400

401

402

403

404

405

406

407

408

409

410

411

412

413

414

415

416

417

418

419

420

expression were observed (Fig 3A,B). Please note that as our control sample had only a single replicate, these findings are not as well supported as our $3{ }^{\circ} \mathrm{C}$ vs $5{ }^{\circ} \mathrm{C}$ comparison. In the comparison of the $3^{\circ} \mathrm{C}$ vs $5^{\circ} \mathrm{C}$ treatments, which do have replicates, there was no difference in significant $\mathrm{GO}$ category expression between our 3 and $5{ }^{\circ} \mathrm{C}$ samples, and we infer that this is due to only minor changes between 3 and $5{ }^{\circ} \mathrm{C}$. These contigs change little in expression, and from their values at $3{ }^{\circ} \mathrm{C}$ do not (or can not) alter their levels any further to adjust to the additional stress at $5^{\circ} \mathrm{C}$.

In our single control vs duplicate $3{ }^{\circ} \mathrm{C}$ samples (Fig 3A), GO category representation changed significantly in a number of categories. Among the $\mathrm{GO}$ categories downregulated at 3 'C , 'immune response', 'signal transduction' 'serine type endopeptidase inhibitor activity' and 'pantothenate biosynthetic pathway' were significantly more prevalent there than in our overall set. These GO terms indicate that immune responses and normal bodily maintenance may be perturbed by thermal stress. In contrast, GO terms associated with ribosomes and structural molecules are under-represented in this set, and therefore contigs coding for these are not present in the downregulated complement after heat exposure. This is similar to the results observed in Guzman and Conaco (2016) ${ }^{34}$, as discussed further below.

In the $\mathrm{GO}$ categories upregulated at $3{ }^{\circ} \mathrm{C}$, it again seems that normal metabolism is less important for response to thermal stress than cytoskeletal responses and growth factor activity. Many GO terms related to metabolic activity (e.g. 'phosphate-containing compound metabolic process', 'organic substance biosynthetic process') are under-represented in these genes relative to our overall library, while GO terms linked to microtubules and other cytoskeletal components are significantly over-represented. Taken in concert with our GO term distribution findings from downregulated genes, it seems that structural componentry is significantly upregulated in response to a $3{ }^{\circ} \mathrm{C}$ heat shock, and cytoskeletal proteins can be involved in stress response ${ }^{65}$.

Many of these findings are mirrored in our single control vs duplicate $5{ }^{\circ} \mathrm{C}$ samples (Fig 3B). Four GO categories, 'intracellular non-membrane-bounded organelle', 'cytoplasmic part', 'pantothenate biosynthetic process' and 'signal transduction', had similar changes in abundance in downregulated contigs from our 3 and $5{ }^{\circ} \mathrm{C}$ treatments compared to the control, and 'growth factor activity' was significantly over-represented in contigs upregulated in response to increased temperature in both samples. These have been underlined in the figure. A small number of additional categories were significantly changed in our $5{ }^{\circ} \mathrm{C}$ treatment but not observed in our $3^{\circ} \mathrm{C}$ treatment, including a number of categories related to the biosynthesis of specific molecular and cellular components. For instance, the category 'cellular macromolecule 
421 biosynthetic process', is less prevalent in downregulated genes, (and therefore not itself present 422 in downregulated contigs), while 'tyrosine biosynthetic process' and other categories are over423 represented in up-regulated genes, reflecting underlying transcriptional activity in that regard, 424 mirroring our findings in the $3{ }^{\circ} \mathrm{C}$ treatment.

425 Previous work ${ }^{34}$ observed the upregulation of a number of protective and signalling426 related pathways after heat shock. We see a similar pattern in our data, but the exact categories 427 are not seen in Isodictya as in their warm-water Haliclona tubifera. Protective mechanisms in 428 common with the Haliclona results include those linked to antioxidant activity and immune 429 response activation, but do not include the toll-like receptor (TLR) signaling pathway. We also 430 observe similar broad representation of cellular ion homeostasis, messenger-mediated 431 pathways, transporter activity and microtubule-based movement-linked categories, but do not 432 see specifically calcium-mediated signaling categories, unlike those seen in their data.

While most of the observed categories in our data are quite broad and reflect changes in 434 a number of gene families, we can observe some quite specific changes in expression. For 435 example, the 'Tumor necrosis factor receptor binding' category is over-represented in 436 downregulated contigs at $5{ }^{\circ} \mathrm{C}$. This means that TNF receptor binding genes are not as common 437 in the $5{ }^{\circ} \mathrm{C}$ treatment, suggesting that this gene family is not utilised as prevalently after heat 438 shock. This finding was born out by our analysis of discrete contig up- and down-regulation, as 439 discussed in detail elsewhere in this manuscript.

\section{Identification of Target Genes}

$442 \quad$ Given the large number of genes with no gene ontology assignment in the top 20-most differentially expressed complement, we also adopted a target gene approach to identify the impact of heat exposure on many well-known gene families known from previous work. From the lists of differentially expressed genes, we have selected genes previously identified as playing a role in thermal response for further study, as well as transcription factors with potential roles as cellular mediators of this process, as can be seen in Table 4. Full details of the exact expression levels of all these genes can be found in Supplementary File 4.

Heat shock proteins (HSPs) were prevalent in these complements. We obtained 4 contigs encoding a full-length sequence, corresponding to four isoforms of the gene encoding for HSP70 and related proteins. These four sequences were designed as A1, A2, B and HSP-er 452 (contigs: TRINITY_DN27082_c0_g1, TRINITY_DN12545_c0_g2, TRINITY_DN24395_c0_g1, 453 and TRINITY_DN20850_c0_g1_i1, respectively). The alignment of these four putative HSP70 454 sequences from Isodictya sp. alongside those previously described in sponges and other 
455 marine invertebrates, as well as related species, can be seen in Fig 4A (Full sequences, along 456 with alignment, Supplementary File 6).

457 The full-length sequence of these proteins showed the presence of three classical 458 signature motifs of the HSP70 family (IDLGTTYS; IIDLGGGTFDVSIL; IVLVGGSTRIPKI/VQK) 459 and the ATP/GTP binding site (Fig 4B). These four forms of HSP70 in Isodictya possess 460 relatively low sequence similarity (between $41.4 \%$ and $68.1 \%$ amino acid identity), and 461 individual isoforms are more closely related to some previously described forms, which may 462 indicate that HSP70A and B are ancestrally shared paralogues within the Porifera (Fig 4A). The 463 HSP70A1 and 2 genes are most closely related to the non-inducible or HSP70 cognate (HSC) 464 described for others invertebrates and vertebrates (Fig 4, Supplementary File 7). Their C465 terminal region contains five repeats of GGMP motif. The tetrapeptide motif GGMP repeats are 466 thought to be involved in co-chaperone-binding activities of constitutive forms ${ }^{66}$. HSP-A 467 sequences have a terminal motif (EEVD) indicating their cytoplasmatic localisation ${ }^{67}$. We do not 468 observe a clear mitochondrial-located HSP70 homologue, but HSP-er shows clear homology to 469 known endoplasmic reticulum isoforms, and clear sequence similarity to those from both vertebrate and invertebrate species (Fig 4B).

471 In contrast, the isoform HSP70B showed high sequence similarity to the HSP70 472 sequence of Xestospongia testudinaria (75.4\%) and this sequence does not possess 473 tetrapeptide repeat sequences at the C-terminal (Fig 4B). HSP-B is therefore likely the 474 "inducible" HSP gene in this species. It was up-regulated during thermal stress in this 475 experiment, listed among the most strongly-changed in expression (Table 3), and thus shares 476 characteristics of inducible isoforms previously described in other marine invertebrates such as 477 oysters and krill (see ${ }^{66,68}$ for more details).

478 In other species, the transcription of HSPs is upregulated in response to a variety of stresses ${ }^{69}$, preventing the mis-folding and aggregation of proteins, but is notably absent in some species of Antarctic fish where HSPs are constitutively turned on in some cases ${ }^{67}$. HSPs however play a clear role in temperature response in Antarctic invertebrates ${ }^{17}$. Given the upregulation of isoform $B$ here, it is clear that this role is conserved in sponges, and this collaborates findings previously in this phylum ${ }^{37,70}$.

A number of contigs with sequence similarity to the Tumor necrosis factor gene family 485 were observed in our dataset, in both our upregulated and downregulated complements (n.b. 486 different contigs were present in the two complements). This finding dovetails with the observation of this in the GO term over-representation analysis for contigs downregulated in our $5{ }^{\circ} \mathrm{C}$ treatment. This cytokine family is responsible for regulating cell death through ubiquitins, 
489 but also has other functions, including the regulation of cell survival, proliferation and 490 differentiation ${ }^{71,72}$ and the downregulation of some members of this class and upregulation of 491 others possibly reflects changing cellular processes within our sponge samples of interest to 492 those studying the molecular processes underlying thermal stress responses. A single gene 493 linked to this has previously been observed to be upregulated after heat shock in sponges 494 (TNFAIP334) and the additional sequences observed here suggests the possible role of these 495 genes in linking with ubiquitins and mediating cell death and protein degradation in Porifera after 496 heat exposure.

497 The ubiquitin related genes themselves, which play essential roles in protein degradation 49873,74 , were well recovered in our transcriptome. Fig 5 shows our annotation of the proteolytic 499 pathway mediated by these genes, as annotated by bi-directional best blast hit. Of genes that 500 are missing, few (12) may be truly absent from our transcriptomic resource- others are also 501 absent from $A$. queenslandica and may be absent ancestrally. Three components of this 502 pathway, TRINITY_DN31115_c0_g1 (UBE2M; UBC12; ubiquitin-conjugating enzyme E2 M), 503 TRINITY_DN8356_c0_g2 (UBC1; ubiquitin-conjugating enzyme, aka HIP2; huntingtin 504 interacting protein 2) and TRINITY_DN25219_c0_g1 (UBE3A; E6AP; ubiquitin-protein ligase $505 E 3 A$ ) were significantly upregulated in our dataset in response to heat exposure. These genes, 506 representing E2 and HECT E3 type ubiquitin conjugating genes could play specific roles in the 507 degeneration of misfolded and degenerated peptides after heat exposure, correlates well with 508 previous findings in other sponge species such as Haliclona tubifera ${ }^{34}$ and the specific genes 509 are worth further consideration as potential mediators of this intracellular protective response.

$510 \quad$ We found a number of notable transcription factor and cell signalling pathways in our up511 and down-regulated gene lists, including genes in the Notch, Wnt, TNF, Sox and TGF- $\beta$ 512 pathways. These are sometimes recovered in heat stress studies, with the exact families used 513 varying according to study species as detailed below. These genes do not need to be the most 514 up-/down-regulated genes to have a noted effect on transcription, and they represent intriguing 515 targets as possible controllers of wider processes of molecular adaptation.

516 Other examples of key cell signalling molecules identified in our study include members 517 of the Sox and Wnt gene families, notably Sox2 and dishevelled. These are possibly key in the 518 control of growth response to heat stress - Sox2 in particular is known for its role in the control 519 of pluripotency in stem cell lineages ${ }^{75}$. Growth will both be promoted by higher temperatures, 520 but also necessary for repairing tissue damage caused by exposure to deleterious conditions. 521 However, by far the most commonly observed family of cell signalling molecules are 522 representatives of the BMP/TGF- $\beta$ pathway. A variety of contigs with blast similarity to the TGF- 
$523 \beta$ family of signalling molecules were observed in our differentially expressed complements,

524 including a variety of contigs annotated as bone morphogenic proteins and growth differentiation

525 factors, as well as one eyed pinhead and the Tolloid metalloprotease, which act to modulate 526 TGF- $\beta$ signalling. These molecules are well known as modulators of cell fates, but any role in 527 controlling response to thermal stress has not before been noted in sponges. It is possible that 528 these molecules are acting downstream of HSP70 (as noted by ${ }^{76,77}$ ) or as part of the control of 529 molecular response to physical damage caused by high temperatures 79 . However, the 530 phylogenetic distance between the organisms where this has been studied and sponges is vast, 531 and more targeted analysis is necessary to discern the true roles of these crucial molecules in 532 this Phylum.

533 We noted the presence of the Hedgehog family of genes in our dataset, with both 534 hedgehog precursor (TRINITY_DN46355_c0_g1_i1) and indian hedgehog 535 (TRINITY_DN16789_c0_g1_i1) automatically annotated - the latter will be a naming artifact 536 from annotation, as indian hedgehog is a chordate novelty generated by duplication into 537 paralogues. Both contigs therefore represent variants of the hedgehog gene itself. These could 538 perform key roles in the regulation of response to thermal stress, as they are instrumental in the 539 fine-tuning of cell differentiation responses ${ }^{78}$. We also note the presence of members of the 540 Notch signalling cascade in the differentially expressed complements following heat stress 541 (e.g.TRINITY_DN30424_c0_g1_i1 delta and Notch-like epidermal growth factor-related 542 receptor-like), with Notch-related contigs downregulated after exposure to both 3 and $5{ }^{\circ} \mathrm{C}$ 543 treatments. This possibly reflects changes in how cell differentiation is occurring. Hedgehog is 544 often noted as a promoter of stem cell proliferation, and the initial stages of heat stress 545 response may involve this, in concert with genes such as Sox2 as noted above.

$546 \quad$ In the most similar study to this work previously performed, in the warm water sponge $H$. 547 tubifera from Philippines ${ }^{34}$, multiple $G$ protein coupled receptors (GPCRs) were noted as 548 differentially expressed. In that experiment, sponges with a normal growth temperature of $29^{\circ} \mathrm{C}$ 549 were exposed to $32^{\circ} \mathrm{C}$ and $34^{\circ} \mathrm{C}$ for between 4 and 12 hours. GPCR genes are posited to allow 550 these sponges to monitor and respond to their environment effectively. Several families of 551 GPCR were noted as effected by heat exposure in H. tubifera, including glutamate, rhodopsin 552 and secretin GPCRs. None of these were observed here, and therefore the light and contraction 553 responses seen in $H$. tubifera on exposure to heat stress do not seem to be conserved in 554 Isodictya sp. Instead, two families of orphan GPCR, 157 and 161, were noted in our sample. 555 The roles of these specific GPCR in sponges, and in general outside the Chordata, are poorly 556 understood, but their marked up-regulation here, and the absence of the plethora of differentially 
557 expressed GPCR seen in $H$. tubifera, suggests that these explicit genes may play specific roles

558 in sensing or recovering from heat exposure in this particular species.

559 Marine polar organisms are interesting models for studies on the noxious effects of 560 reactive oxygen species (ROS) in cold waters. In order to cope with the formation of deleterious

561 ROS, some Antarctic marine invertebrates express enzymes and low-molecular weight 562 'scavengers' 79. The accumulation of ROS during heat stress has been shown in previous 563 studies on Antarctic marine species ${ }^{80,81}$, and are important to these species given the higher 564 levels of dissolved oxygen seen in cooler Antarctic waters. In our study, we have obtained a 565 good sequence coverage for several enzymes implicated in antioxidant defense 566 (Supplementary File 8). Two kinds of superoxide dismutase (SOD), each with different isoformal 567 variants, were identified in Isodictya sp. which are differentiated by the type of metal associated 568 with its active site of the enzyme: two contigs for manganese SOD 569 (TRINITY_DN32241_c0_g1_i1 and TRINITY_DN3280_c0_g2_i1) and four contigs for a 570 copper/zinc SOD (TRINITY_DN22531_ c0_g1_i1; TRINITY_DN17486_c0_g1_i1;

571 TRINITY_DN_65_c0_g1_i1; TRINITY_DN35772_c0_g1_i1). The SOD enzyme catalyze the

572 first reaction in the dismutation of superoxide anions to water and hydrogen peroxide, before the 573 catalase enzyme transforms the hydrogen peroxide into water. This enzyme is represented by 574 three contigs that share high sequence identities with marine invertebrates such as molluscs 575 (TRINITY_DN_6504; 28381; 29099). Another transcript well represented in our dataset was a 576 glutathione S-transferase (GST) which plays a key role in the detoxification of ROS and the 577 regulation of redox balance ${ }^{82}$. In Isodictya sp. seven contigs were identified with high sequence 578 similarity to GSTs, a complex family of genes with multiple intracellular functions. Previous 579 studies have highlighted the upregulation of oxidative response and antioxidant genes in 580 response to thermal challenge in sponges, as also observed in corals ${ }^{83}$. In our data, we observe 581 the upregulation of several contigs with strong similarity to genes with antioxidant activity, 582 glutaredoxin (TRINITY_DN32811_c0_g1_i1) and thioredoxin (TRINITY_DN32811_c0_g1_i3) ${ }^{34}$. 583 We also see a contig upregulated with similarity to oxidative stress-induced growth inhibitor 2584 like (TRINITY_DN30012_c0_g1_i1), which could play a role in downstream organisation after 585 the detection of an oxidative stress state. It seems possible that these sponges are under 586 severe oxidative stress, and the expression of these genes reflects this, although the 587 experiment was stopped before any outward signs of damage (e.g. necrosis) were observed.

588 The presence of allograft inflammatory factor (TRINITY DN_12683_c0_g1_i1) in our 589 datasets was noted as these have been previously studied in Antarctic species such as the sea 590 urchin Sterechinus neumayeri84. The full Isodictya AIF-1 sequence was recovered, and has a 
591 high sequence similarity with that known from the sponge Suberites domuncula, and has two 592 conserved calcium binding motifs known as EF hands (Fig 6). AIF-1 sequences from several 593 invertebrate and vertebrate species were aligned and showed relatively high levels of 594 conservation of the protein with both groups. Phylogenetic analyses generated a congruent tree 595 positioning the AIF from sponges in a cluster with corals, distinct from vertebrate sequences. In 596 general, allograft inflammatory factor is known for its role in recovery from injury, rather than any 597 specific role in protecting against heat shock $^{85}$. It has been studied in sponges previously ${ }^{86}$, 598 where it has been shown to act to activate immunocyte-like activity, as well as in protection 599 immediately after trauma. In the Japanese oyster Crassostrea gigas AIF-1 stimulates hemocyte 600 immune activation by enhancing phagocytosis and expression of inflammatory cytokines ${ }^{87}$. Its 601 role in the thermal stress response might therefore be in protection against infection, rather than 602 directly in tissue repair, but both these processes are undoubtedly necessary under prolonged 603 periods of acute thermal stress.

604 That Antarctic species of sponge utilize many of the same pathways to respond to 605 thermal stress as warmer water species is a useful if unsurprising finding. Their efficacy at 606 moderating response to different levels of stress does however seem to be diminished, with 607 many of these genes expressed at both 3 and $5{ }^{\circ} \mathrm{C}$, with no significant difference in their 608 expression levels between these temperatures, as noted elsewhere in this work.

609

610

Poriferan Responses to Temperature Stress

611 Our results, when considered alongside previous findings in sponges from other 612 latitudes, corroborate previous conclusions regarding their transcriptomic response to acute 613 thermal stress, while suggesting specifically that cold-adapted sponges may have a limited 614 range of tolerance to increased temperatures. The changes in transcription which occurred in 615 our samples after acute short-term thermal exposure suggested that a poriferan heat-response 616 is activated by increased temperatures, and is present in this species. The complements of all 4 617 replicates in both $3{ }^{\circ} \mathrm{C}$ vs $5^{\circ} \mathrm{C}$ conditions were very similar in both overall pattern and individual 618 composition, with differentially regulated contigs often perturbed in common at both 619 temperatures. Previous work on sponges from other latitudes ${ }^{34,51}$ showed that HSP70 and 620 ubiquitin-related genes were specifically upregulated in response to thermal stress. Our work 621 echoes this finding, observing the activation of similar genes, such as oxidation-stress related 622 genes. The nature of the thermal stress response therefore is broadly similar to that seen in 623 other sponge species. What may differ in Antarctic species of sponge is the limits of tolerance. 
624

625

626

627

628

629

630

631

632

633

634

635

636

637

638

639

640

641

642

643

644

645

646

647

648

649

650

651

652

653

654

655

656

657

In other sponges, the degree and type of transcriptional response is temperaturedependent, with specific genes activated at different temperatures ${ }^{36}$, where the holobiont changes, or ${ }^{34}$, where the sponge itself adapts its transcription). In contrast, our findings showed few significant differences in the transcriptional response of sponges at 3 and $5{ }^{\circ} \mathrm{C}$ (where we have replicate samples, and can thus be confident of the veracity of these results). We also do not see changes in quite the same genes, with the absence of differentially expressed GPCR and toll-like receptor (TLR) signaling genes in our data a notable difference. While previous research has demonstrated that some Antarctic species are not able to respond to additional increases in seawater temperature, others, such as Nacella concinna or Laternula elliptica showed a classic thermal stress response with over-expression of heat stress chaperones.

A number of differences are noted in the response of cold water sponges here, when contrasted with those of warm-water species ${ }^{34}$. Particularly, there does not seem to be the degree of incremental change that can be seen in the transcriptional profile of warm water species on exposure to increasing temperatures., at least in the time frame examined here. Since our experiment exposed sponges to acute stress, our results did not test whether coldadapted sponges could, in time, adapt to sequentially higher temperatures, and this would be a useful follow-up experiment to those described here. It may be possible that with a period of acclimation, sequential rises in temperature can be met by successive rounds of molecular adaptation. However, at present we cannot speculate as to whether that is possible in this species.

\section{Conclusions}

Climate change is a pressing issue globally, and will have a range of effects on organisms worldwide, involving both long-term and acute exposure to increased temperatures. While some of these effects are more obvious or better studied than others, it is some of the least-studied species which will bear the brunt of these conditions, and these will have a variety of knock-on effects. Here we have studied one such species, a locally abundant sponge, specialised to life in Antarctic conditions. We have generated a reference transcriptome from a small number of replicate samples exposed to acute thermal stress, and identified the molecular responses that these species use to adjust to these conditions. Further, we have demonstrated the clear stress that even a modest increase in temperature over a short time frame (in this case, 4 hours) will place on such a specialist species.

Using this data, we have made several comparisons between a single control sample and replicate $3{ }^{\circ} \mathrm{C}$ and $5{ }^{\circ} \mathrm{C}$ heat shock samples. Comparisons between our replicate samples 
658 indicate Isodictya already exercises a full measure of transcriptomic response to ambient 659 temperatures of $3{ }^{\circ} \mathrm{C}$, and further stress at $5{ }^{\circ} \mathrm{C}$ leaves it little further "wriggle room", at least 660 when considering acute responses such as those tested here. Whether this stress results, in the 661 wild, in the death of these sponges, or whether, given time, they will adapt to increased 662 temperatures, is at present uncertain. However, in the interim the results presented here will 663 allow us to begin to understand the impact of increased temperatures on these still under664 investigated, but nonetheless vital, species.

665

\section{Animal Ethics}

$667 \quad$ No animal ethics approval procedure exists for Porifera, and no permission was required 668 to perform the experiments described in this manuscript.

669

\section{Acknowledgements}

671 The authors thank the members of their laboratories for all their support, comradeship 672 and scholarly input. We are also grateful to the dive team, Leslie Novoa, Juana Levihuan and 673 INACH personnel at Yelcho Station for their help during fieldwork activities in Antarctica. 674 Cristian Lagger provided the underwater photograph of Isodictya sp. We thank the editors and 675 reviewers for their aid in assessing this manuscript. This work was supported by 676 CONICYT/FONDECYT/INACH/INICIACION/\#11150129. The work of NJK was made possible 677 by the ADAPTOMICS MSCA [IF750937] under the Horizon 2020 program. This paper 678 contributes to the SCAR Antarctic Thresholds - Ecosystem Resilience and Adaptation (Ant679 ERA) programme. 
682

683

684

685

686

687

688

689

690

691

692

693

694

695

696

697

698

699

700

701

702

703

704

705

706

707

708

709

710

711

712

713

714

715

\section{References}

1. Bell JJ. The functional roles of marine sponges. Estuar Coast Shelf Sci. $2008 ; 79: 341-353$.

2. De Goeij JM, Van Oevelen D, Vermeij MJ, Osinga R, Middelburg JJ, de Goeij AF \& Admiraal W. Surviving in a marine desert: the sponge loop retains resources within coral reefs. Science. $2013 ; 342: 108-110$.

3. McClintock JB, Amsler CD, Baker BJ \& van Soest RWM. Ecology of Antarctic marine sponges: an overview. Int Comp Biol. 2005;45, 359-368.

4. Cárdenas CA, Newcombe EM, Hajdu E, Gonzalez-Aravena M, Geange SW \& Bell JJ.. Sponge richness on algae-dominated rocky reefs in the Western Antarctic Peninsula and the Magellan Strait. Polar Res. $2016 ; 35,30532$.

5. Cárdenas CA \& Montiel A. Coexistence in Cold Waters: Animal Forests in SeaweedDominated Habitats in Southern High Latitudes in Marine Animal Forests: The Ecology of Benthic Biodiversity Hotspots (ed. Rossi S., Bramanti L., Gori A. \& Orejas C.) 1-20 (Springer, 2017).

6. Gutt J, Cummings V, Dayton P, Isla E, Jentsch A \& Schiaparelli S. Antarctic marine animal forests: three-dimensional communities in Southern Ocean ecosystems. Marine Animal Forests: The Ecology of Benthic Biodiversity Hotspots (ed Rossi S, Bramanti L, Gori A \& Orejas C.) 1-29 (Springer, 2017).

7. Bell JJ, McGrath E, Biggerstaff A, Bates T, Cárdenas CA \& Bennett H. Global conservation status of sponges. Cons Biol. 2015;29,42-53.

8. Carballo JL \& Bell JJ. Climate Change and Sponges: An Introduction in Climate Change, Ocean Acidification and Sponges (ed. Carballo JL \& Bell JJ) 1-10 (Springer, 2017)

9. Turner J, Lu H, White I, King JC, Phillips T, Hosking JS, Bracegirdle TJ, Marshall GJ, Mulvaney R \& Deb P. Absence of 21st century warming on Antarctic Peninsula consistent with natural variability. Nature. 2016;535, 411.

10. Stenni B, Curran MA, Abram N, Orsi A, Goursaud S, Masson-Delmotte V, Neukom R, Goosse H, Divine D, Van Ommen T \& Steig EJ. Antarctic climate variability on regional and continental scales over the last 2000 years. Climate of the Past. 2017;13, 1609-1634.

11. IPCC Climate Change 2014: Impacts, Adaptation, and Vulnerability in Intergovernmental Panel on Climate Change. Working Group II Report (IPCC, 2014).

12. Peck, L. 2018 Antarctic marine biodiversity: adaptations, environments and responses to change. In: Hawkins SJ, Evans AJ, Dale AC, Firth LB and Smith IP, (eds.) Oceanography and Marine Biology: An Annual Review, Volume 56. Taylor and Francis, 105-236. 
716 13. Ingels J, Vanreusel A, Brandt A, Catarino Al, David B, De Ridder C, Dubois P, Gooday AJ, 717 Martin P, Pasotti F \& Robert H. Possible effects of global environmental changes on Antarctic 718 benthos: a synthesis across five major taxa. Ecol Evol. 2012;2, 453-485.

719 14. Somero GN. The physiology of climate change: how potentials for acclimatization and 720 genetic adaptation will determine 'winners' and 'losers'. J Exp Biol. 2010;213, 912-920.

721 15. Peck L, Morley S, Richard J \& Clark M. Acclimation and thermal tolerance in Antarctic 722 marine ectotherms. J Exp Biol. 2014;217, 16-22.

723 16. Suckling CC, Clark MS, Richard J, Morley SA, Thorne MA, Harper EM \& Peck LS. Adult 724 acclimation to combined temperature and $\mathrm{pH}$ stressors significantly enhances reproductive 725 outcomes compared to short-term exposures. J Anim Ecol. 2015;84, 773-784.

726 17. Clark MS, Sommer U, Sihra JK, Thorne MA, Morley SA, King M, Viant MR \& Peck LS. 727 Biodiversity in marine invertebrate responses to acute warming revealed by a comparative 728 multi-omics approach. Glob Change Biol. 2017;23: 318-330.

729 18. Ramsby BD, Hoogenboom MO, Smith H A, Whalan S \& Webster NS. The bioeroding 730 sponge Cliona orientalis will not tolerate future projected ocean warming. Sci Rep. 2018;8, 7318302.

732 19. Duckworth AR, West L, Vansach T, Stubler A \& Hardt M. Effects of water temperature and $733 \mathrm{pH}$ on growth and metabolite biosynthesis of coral reef sponges. Mar Ecol Prog Ser. 2012;462, 734 67-77.

735 20. Kelmo F, Bell JJ \& Attrill MJ. Tolerance of sponge assemblages to temperature anomalies: 736 resilience and proliferation of sponges following the 1997-8 El-Nino southern oscillation. 737 2013;PLoS ONE. 8, e76441.

738 21. Strand R, Whalan S, Webster NS, Kutti T, Fang JK, Luter HM \& Bannister RJ. The response 739 of a boreal deep-sea sponge holobiont to acute thermal stress. Sci Rep. 2017;7, 1660.

740 22. Cebrian E, Uriz MJ, Garrabou J \& Ballesteros E. Sponge mass mortalities in a warming 741 Mediterranean Sea: are cyanobacteria-harboring species worse off?. PLoS One. 2011;6, 20211.

742 23. Webster N, Pantile R, Botte E, Abdo D, Andreakis N \& Whalan S. A complex life cycle in a 743 warming planet: gene expression in thermally stressed sponges. Mol Ecol. 2013;22, 18547441868.

745 24. Ettinger-Epstein P, Whalan S, Battershill CN \& de Nys R. Temperature cues gametogenesis 746 and larval release in a tropical sponge. Mar Biol. 2007;153,171-178.

747 25. Massaro AJ, Weisz JB, Hill MS \& Webster NS. Behavioral and morphological changes 748 caused by thermal stress in the great barrier reef sponge Rhopaloeides odorabile. J Exp Mar 749 Biol Ecol. 2012;417, 55-60. 
750 26. Cerrano C, Bavestrello G, Bianchi CN, Cattaneo-vietti R, Bava S, Morganti C, Morri C, Picco

751 P, Sara G, Schiaparelli S \& Siccardi A A catastrophic mass-mortality episode of gorgonians and

752 other organisms in the Ligurian Sea (North-western Mediterranean), summer 1999. Ecol Lett.

753 2000;3, 284-293.

754 27. Peck LS. Prospects for survival in the Southern Ocean: vulnerability of benthic species to 755 temperature change. Antarct Sci. 2005;17, 497-507.

756 28. Klinck JM, Hofmann EE, Beardsley RC, Salihoglu B \& Howard S. Water-mass properties

757 and circulation on the west Antarctic Peninsula Continental Shelf in Austral Fall and Winter

758 2001. Deep Sea Res II: Topical Studies in Oceanography, 51, 1925-1946 (2004).

759 29. Cárdenas $C A$, González-Aravena M \& Santibañez PA. The importance of local settings:

760 within-year variability in seawater temperature at South Bay, Western Antarctic Peninsula.

761 PeerJ. 2018;6, e4289.

762 30. Cahais V, Gayral P, Tsagkogeorga G, Melo-Ferreira J, Ballenghien M, Weinert L, Chiari Y,

763 Belkhir K, Ranwez V \& Galtier N. Reference-free transcriptome assembly in non-model animals

764 from next-generation sequencing data. Mol Ecol Resources. 2012;12, 834-845.

765 31. Pérez-Porro AR, Navarro-Gómez D, Uriz MJ \& Giribet, G. A NGS approach to the 766 encrusting Mediterranean sponge Crella elegans (Porifera, Demospongiae, Poecilosclerida):

767 transcriptome sequencing, characterization and overview of the gene expression along three life 768 cycle stages. Mol Ecol Res. 2013;13, 494-509.

769 32. Riesgo A, Farrar N, Windsor PJ, Giribet G \& Leys SP. The analysis of eight transcriptomes 770 from all poriferan classes reveals surprising genetic complexity in sponges. Mol Biol Evol. $7712014 ; 31,1102-1120$.

772 33. Fernandez-Valverde SL, Calcino AD \& Degnan BM. Deep developmental transcriptome 773 sequencing uncovers numerous new genes and enhances gene annotation in the sponge 774 Amphimedon queenslandica. BMC Genom.2015;16, 387.

775 34. Guzman $C$ \& Conaco C. Gene expression dynamics accompanying the sponge thermal 776 stress response. PLoS ONE. 2016;11, e0165368.

777 35. Erwin PM, Pita L, Lopez-Legentil S \& Turon X. Stability of sponge-associated bacteria over 778 large seasonal shifts in temperature and irradiance. Appl Environ Microbiol. 2012;78, 73587797368.

780 36. Fan L, Liu M, Simister R, Webster NS \& Thomas T. Marine microbial symbiosis heats up: 781 the phylogenetic and functional response of a sponge holobiont to thermal stress. ISME J. $782 \quad 2013 ; 7,991-1002$. 
783 37. Pita L, Turon X, Lopez-Legentil S \& Erwin PM. Host rules: spatial stability of bacterial 784 communities associated with marine sponges (Ircinia spp.) in the Western Mediterranean Sea. 785 FEMS Microbiol Ecol. 2013;86, 268-276.

786 38. Simister R, Taylor MW, Tsai $P$ \& Webster N. Sponge-microbe associations survive high 787 nutrients and temperatures. PLoS ONE. 2012;7, e52220.

788 39. Lopez-Legentil S, Song B, McMurray SE \& Pawlik JR. Bleaching and stress in coral reef 789 ecosystems: hsp70 expression by the giant barrel sponge Xestospongia muta. Mol Ecol. 790 2008;17, 1840-1849.

791 40. Andrews S. FastQC: A quality control tool for high throughput sequence data. Babraham 792 Bioinformatics. 2010; http://www.bioinformatics.babraham.ac.uk/projects/fastqc/.

793 41. Bolger AM, Lohse $M$ \& Usadel B. Trimmomatic: a flexible trimmer for Illumina sequence 794 data. Bioinformatics. 2014;30, 2114-2120.

795 42. Li H. Seqtk: a fast and lightweight tool for processing FASTA or FASTQ sequences, Github. 796 2013; https://github.com/lh3/seqtk.

797 43. Grabherr MG, Haas BJ, Yassour M, Levin JZ, Thompson DA, Amit I, Adiconis X, Fan L, 798 Raychowdhury $\mathrm{R}$, Zeng $\mathrm{Q}$ \& Chen Z. Full-length transcriptome assembly from RNA-Seq data 799 without a reference genome. Nat Biotechnol. 2011;29, 644-652.

800 44. Schmieder R \& Edwards R. Fast identification and removal of sequence contamination from 801 genomic and metagenomic datasets. PLoS One. 2011;6, e17288.

802 45. Altschul SF, Gish W, Miller W, Myers EW \& Lipman DJ. Basic local alignment search tool. J. 803 Mol Biol. 1990;215, 403-10.

804 46. Katoh $\mathrm{K}$ \& Standley DM. MAFFT multiple sequence alignment software version 7: 805 improvements in performance and usability. Mol Biol Evol. 2013;30, 772-780.

806 47. Castresana J. Selection of conserved blocks from multiple alignments for their use in 807 phylogenetic analysis. Mol Biol Evol. 2000;17, 540-552.

808 48. Silvestro, M. raxmIGUI: a graphical front-end for RAxML. Organis Div Evol. 2012;12, 335809337.

810 49. Kumar S, Stecher G \& Tamura K. MEGA7: molecular evolutionary genetics analysis version 8117.0 for bigger datasets. Mol Biol Evol. 2016;33, 1870-1874.

812 50. Larkin MA, Blackshields G, Brown NP, Chenna R, McGettigan PA, McWilliam H, Valentin F, 813 Wallace IM, Wilm A, Lopez R \& Thompson JD. Clustal W and Clustal X version 2.0. 814 Bioinformatics. 2007;23, 2947-2948. 
815 51. Gouy M, Guindon S \& Gascuel, O. SeaView version 4: a multiplatform graphical user 816 interface for sequence alignment and phylogenetic tree building. Mol Biol Evol. 2009;27, 221817224.

818 52. Simao FA, Waterhouse RM, loannidis P, Kriventseva EV \& Zdobnov EM. BUSCO: 819 assessing genome assembly and annotation completeness with single-copy orthologs. 820 Bioinformatics. 2015;31, 3210-3212.

821 53. Conesa A, Götz S, García-Gómez JM, Terol J, Talón M \& Robles M. Blast2GO: a universal 822 tool for annotation, visualization and analysis in functional genomics research. 823 Bioinformatics.2005;15, 3674-3676.

824 54. Moriya Y, Itoh M, Okuda S, Yoshizawa AC \& Kanehisa M. KAAS: an automatic genome 825 annotation and pathway reconstruction server. Nucleic Acids Res. 2007;35, 182-185.

826 55. Li B \& Dewey CN. RSEM: accurate transcript quantification from RNA-Seq data with or 827 without a reference genome. BMC Bioinformat. 2011;12, 323.

828 56. Langmead B \& Salzberg SL. Fast gapped-read alignment with Bowtie 2. Nat Methods. 829 2012;9, 357-359.

830 57. Robinson MD, McCarthy DJ \& Smyth GK. edgeR: a Bioconductor package for differential 831 expression analysis of digital gene expression data. Bioinformatics. 2010;1,139-140.

832 58. Benjamini $Y$ \& Hochberg $Y$. Controlling the false discovery rate: a practical and powerful 833 approach to multiple testing. J Royal Stat Soc B. 1995;57, 289-300.

834 59. Hansen KD, Brenner SE \& Dudoit S. Biases in Illumina transcriptome sequencing caused by 835 random hexamer priming. Nucleic Acids Res. 2010;38, e131.

836 60. Woese CR, Kandler O \& Wheelis ML. Towards a natural system of organisms: proposal for 837 the domains Archaea, Bacteria, and Eucarya. PNAS USA. 1990;87, 4576-4579.

838 61. Kenny NJ, de Goeij JM, de Bakker DM, Whalen CG, Berezikov E \& Riesgo A. Towards the 839 identification of ancestrally shared regenerative mechanisms across the Metazoa: a 840 transcriptomic case study in the demosponge Halisarca caerulea. Mar Genom. 2018;37, 135841147.

842 62. Cerrano C, Arillo A, Bavestrello G, Calcinai B, Cattaneo-Vietti R, Penna A, Sarà M \& Totti C. 843 Diatom invasion in the antarctic hexactinellid sponge Scolymastra joubini. Polar Biol. 2000;23, 844 441-444.

845 63. Cerrano C, Cucchiari E, Di Camillo C, Totti C \& Bavestrello G. The diversity of relationships 846 between Antarctic sponges and diatoms the case of Mycale acerata Kirkpatrick, 1907 (Porifera, 847 Demospongiae). Polar Biol. 2004;27, 231-237. 
848 64. Hofmann GE, Buckley BA, Airaksinen S, Keen JE \& Somero GN. Heat-shock protein 849 expression is absent in the antarctic fish Trematomus bernacchii (family Nototheniidae). J Exp 850 Biol. 2000;203, 2331-2339.

851 65. Serafini L, Hann JB, Kültz D, Tomanek L. The proteomic response of sea squirts (genus 852 Ciona) to acute heat stress: a global perspective on the thermal stability of proteins. ) Comp 853 Biochem Physiol D. 2011 Sep 1;6(3):322-34.

854 66. Cascella K, Jollivet D, Papot C, Léger N, Corre E, Ravaux J, Clark MS \& Toullec JY. 855 Diversification, Evolution and Sub-Functionalization of 70kDa Heat- Shock Proteins in Two 856 Sister Species of Antarctic Krill: Differences in Thermal Habitats, Responses and Implications 857 under Climate Change. PLoS ONE. 2015;10, 0121642.

858 67. Shonhai A, Boshoff A \& Blatch GL. The structural and functional diversity of Hsp70 proteins 859 from Plasmodium falciparum. Prot Sci, 2007;16(9), 1803-1818.

860 68. Piano A, Franzellitti S, Tinti F \& Fabbri E. Sequencing and expression pattern of inducible 861 heat shock gene products in the European flat oyster, Ostrea edulis. Gene. 2005;361, 119-126.

862 69. Craig EA \& Gross CA. Is hsp70 the cellular thermometer?. Trends Biochem Sci. $8631991 ; 16,135-140$.

864 70. Krasko A, Scheffer U, Koziol C, Pancer Z, Batel R, Badria FA \& Müller WE. Diagnosis of 865 sublethal stress in the marine sponge Geodia cydonium: application of the $70 \mathrm{kDa}$ heat-shock 866 protein and a novel biomarker, the Rab GDP dissociation inhibitor, as probes. Aquat Toxicol. 867 1997;37,157-168.

868 71. Vilcek $\mathrm{J} \&$ Lee TH. Tumor necrosis factor. New insights into the molecular mechanisms of its 869 multiple actions. J Biol Chem. 1991;266, .7313-7316.

870 72. Wang $X \&$ Lin $Y$. Tumor necrosis factor and cancer, buddies or foes?. Acta Pharmacologica 871 Sinica. 2008;29, 1275-1288.

872 73. Glickman $\mathrm{MH}$ \& Ciechanover A. The ubiquitin-proteasome proteolytic pathway: destruction 873 for the sake of construction. Physiol Rev. 2002;82, 373-428.

874 74. Mukhopadhyay D \& Riezman H. Proteasome-independent functions of ubiquitin in 875 endocytosis and signaling. Science. 2007;315, 201-205.

876 75. Rizzino A. Sox2 and Oct 3/4: a versatile pair of master regulators that orchestrate the self877 renewal and pluripotency of embryonic stem cells. WIREs Syst Biol Med. 2009;1, 228-236.

878 76. Yao Y, Watson AD, Ji S \& Boström KI. Heat shock protein 70 enhances vascular bone 879 morphogenetic protein-4 signaling by binding matrix Gla protein. Circulation Res. 2009;105, $880 \quad 575-584$. 
881 77. Lee SB, Lim AR, Rah DK, Kim KS \& Min HJ. Modulation of heat shock protein 90 affects

882 TGF- $\beta$-induced collagen synthesis in human dermal fibroblast cells. Tiss Cell. 2016;48, 616883623.

884 78. Ingham PW \& McMahon AP. Hedgehog signaling in animal development: paradigms and 885 principles. Genes Dev. 2001;15, 3059-3087.

886 79. Camus L, Gulliksen B, Depledge M H \& Jones M B. Polar bivalves are characterized by high 887 antioxidant defences. Polar Res. 2005;24,1-2.

888 80. Abele D, Burlando B, Viarengo A \& Pörtner HO. Exposure to elevated temperatures and 889 hydrogen peroxide elicits oxidative stress and antioxidant response in the Antarctic intertidal 890 limpet Nacella concinna. Comp Biochem Physiol B. 1998;120, 425-435.

891 81. Heise K, Puntarulo S, Portner HO \& Abele D. Production of reactive oxygen species by 892 isolated mitochondria of the Antarctic bivalve Laternula elliptica (King and Broderip) under heat 893 stress. Comp Biochem Physiol C. 2003;134, 79-90.

894 82. Kim M, Ahn IY, Cheon J \& Park H. Molecular cloning and thermal stress-induced expression 895 of a pi-class glutathione S-transferase (GST) in the Antarctic bivalve Laternula elliptica. Comp 896 Biochem. Physiol A Mol Integr Physiol, 2009;152, 207-213.

897 83. DeSalvo MK, Voolstra CR, Sunagawa S, Schwarz JA, Stillman JH, Coffroth MA, Szmant AM 898 \& Medina M. Differential gene expression during thermal stress and bleaching in the Caribbean 899 coral Montastraea faveolata. Mol Ecol. 2008;17, 3952-3971.

900 84. Ovando F, Gimpel C, Cardenas C, Da Silva JR, De Lorgeril J \& Gonzalez M. Cloning and 901 expression analysis of allograft inflammatory factor type 1 in coelomocytes of Antarctic sea 902 urchin (Sterechinus neumayeri). J Shellfish Res. 2012;31. 875-883.

903 85. Utans U, Arceci RJ, Yamashita Y \& Russell ME. Cloning and characterization of allograft 904 inflammatory factor-1: a novel macrophage factor identified in rat cardiac allografts with chronic 905 rejection. J Clinic Invest. 1995;95 2954.

906 86. Kruse M, Steffen R, Batel R, Muller IM \& Muller WE. Differential expression of allograft 907 inflammatory factor 1 and of glutathione peroxidase during auto-and allograft response in 908 marine sponges. J Cell Sci. 1999;112, 4305-4313.

909 87. Zhang Y, Li J, Yu F, He X \& Yu Z. Allograft inflammatory factor-1 stimulates hemocyte 910 immune activation by enhancing phagocytosis and expression of inflammatory cytokines in 911 Crassostrea gigas. Fish Shellfish Immunol. 2013;34, 1071-1077.

912

913 914 
915

916

917 Tables

918

919 Table 1: Raw Read Data, Before and After Cleaning

920 Table 2: Statistics, Reference Transcriptome Assembly

921 Table 3: The 20 most up/downregulated contigs in each sample cross-comparison

922 Table 4: Manually identified target genes, identified from BLAST based annotation 923 (BLAST2GO). 
925 Figure Legends

926

927 Figure 1: A) Image of Isodictya sp. collected at South Bay, WAP (10 m depth). B) Sample 928 collection location, Doumer Island, WAP. C) RAxML trees of $28 S$ rRNA under the GTR model 929 from the Isodictya species mentioned in this manuscript, along with those of related species.

930 Note the difference in placement of the samples used in the present manuscript (in green, 931 Isodictya sp., this work) to that of one of the samples sequenced for this work, Isodictya sp. 103 932 (in magenta), which was excluded due to its being identity as a cryptic, but separate, species.

933

934 Figure 2: Differential expression analysis results performed by RSEM/edgeR within the Trinity 935 framework, with "as gene" results shown. A) is the sample correlation matrix for the five samples 936 used in the final cross-comparison. B) shows the relative expression of each differentially 937 expressed contig across all the samples. Note that contigs occurring uniquely in these samples 938 are not included, as detailed in Methods. For both $A$ and $B$, note the areas of the matrix shown 939 in black hues, indicating few measurable differences between-samples.

940

941 Figure 3: Significantly differentially represented GO categories from contigs up/down regulated 942 at 3 and $5{ }^{\circ} \mathrm{C}$ compared to control sample. A) shows categories from our control vs $3{ }^{\circ} \mathrm{C}$ 943 comparison, while B) shows those from the control vs $5{ }^{\circ} \mathrm{C}$ comparison. Those categories 944 represented in both comparisons are underlined.

945

946 Figure 4: A) Maximum likelihood-derived phylogeny (RAxML, LG+I+G) of HSP70 sequences of 947 known homology, together with novel Isodictya sequences (Names in purple). HSP70 948 sequences of Antarctic-resident species are bolded. Boxed as indicated on the figure are the 949 HSP70-B, HSP70-A (HSC) and glucose-regulated 78 kDa HSP70 clades. Numbers at base of 950 nodes indicate bootstrap support (as \%ge of 1000 replicates). 5B: Multiple alignment of different 951 HSP70 isoforms found in Isodictya sp. with (inducible) HSP70-B, sequence at top, HSP70-A 952 (non-inducible heat-shock cognate) central, and below, HSP-mt sequences. These are shown 953 alongside sequences from other species, showing the differences in domain content between 954 isoforms. All HSPs have two main domains: the ATPase domain involved in ATP hydrolysis, 955 and the substrate binding domain, which binds extended polypeptides, as shown at the bottom 956 of the figure. Yellow boxes represent signature domains within HSP70 proteins. The G/P rich 957 terminal region is prominent in HSPC (HSP-B). The EEVD sequence motif allows the 
958 cytoplasmic localisation of HSP and HSC isoforms. Accession numbers as provided in Figure, 959 all sequences are provided, along with alignments, in Supplementary File 6.

960

961 Figure 5: KEGG style map showing recovery of Ubiquitin mediated proteolysis genes in our 962 resource as assessed by bi-directional best blast hit, alongside that of the sequenced genome 963 of Amphimedon queenslandica. Genes noted as present in this resource indicated in green, with 964 those absent in our transcriptome noted in orange if also missing from $A$. queenslandica (and 965 therefore a possible poriferan absence), or red if absent from our resource only (and therefore a 966 likely true absence). A) Canonical Ubiquitin mediated proteolysis. B) Alternative forms of E3 967 (Ubiquitin ligase) complexes.

968

969 Figure 6: Alignment and phylogenetic analysis of the AIF sequences found in our 970 transcriptome. A) The conserved two EF-hand motifs are indicated in the alignment of several 971 AIF-1 from other invertebrate and vertebrate sequences; b) Phylogenetic tree of the AIF-1 family 972 using the $\mathrm{N}-\mathrm{J}$ method. Bootstrap values represent the frequency of appearance (expressed as a 973 percentage) of each clade of 1000 bootstrap replicates; c) Percentage amino acid identities 974 between AlF-1 genes from invertebrates and vertebrates. The GenBank accession numbers for 975 the sequences are as follows: Suberites domuncula CAC38780; Acropora digitifera 976 XP015755194; Orbicella faveolata XP020615825; Amphimedon queenslandica XP003387413; 977 Salmo salar AC169994; Mus musculus; Homo sapiens P55008; Bos taurus NP001071547; Sus 978 crofa P81076; Crassostrea gigas NP001292275; Sterechinus neumayeri ACO40483; Haliotis 979 discus $\mathrm{ABH} 10674$.

980

981 


\section{Figure 1}

Image of Isodictya, sample site and phylogeny

A) Image of Isodictya sp. collected at South Bay, WAP (10 m depth). B) Sample collection location, Doumer Island, WAP. C) RAxML trees of 28S rRNA under the GTR model from the Isodictya species mentioned in this manuscript, along with those of related species. Note the difference in placement of the samples used in the present manuscript (in green, Isodictya sp., this work) to that of one of the samples sequenced for this work, Isodictya sp. 103 (in magenta), which was excluded due to its being identity as a cryptic, but separate, species. 
A)

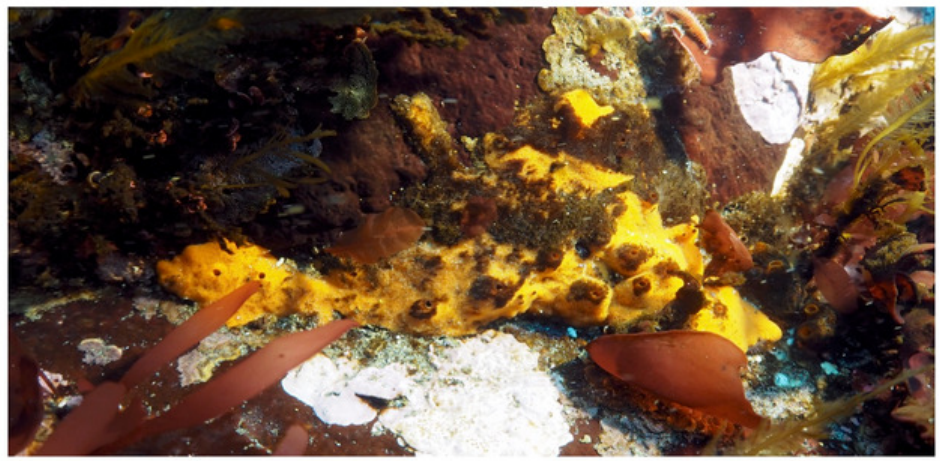

B)

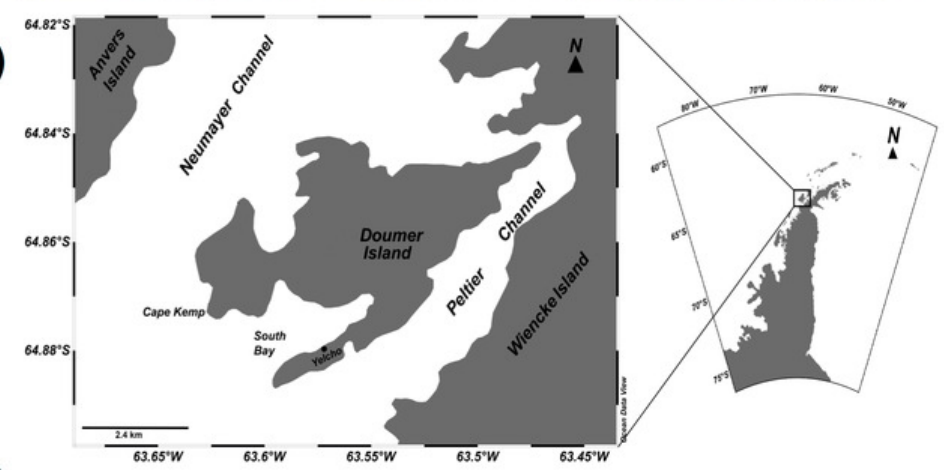

C)

Monanchora arbuscula

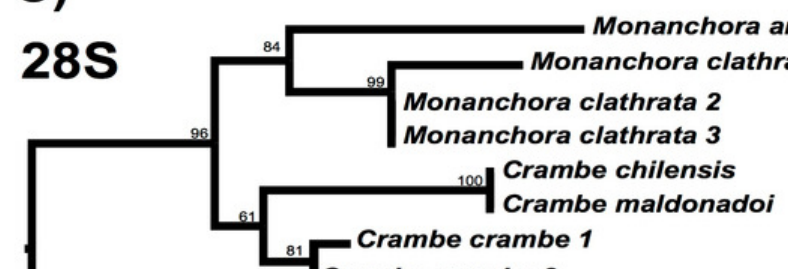

Crambe crambe 2

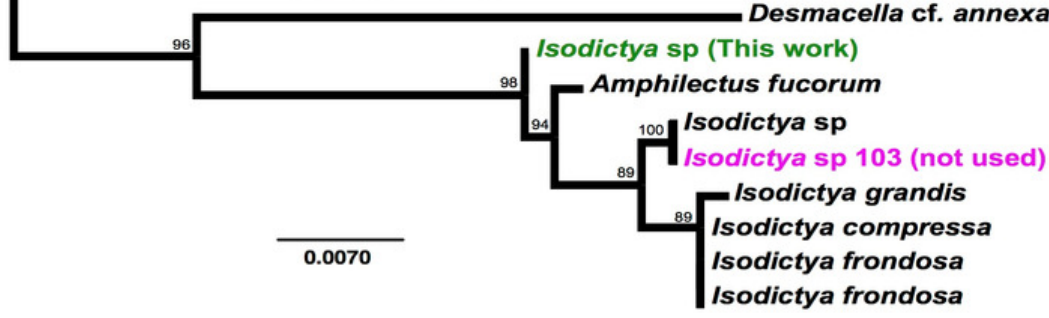




\section{Figure 2}

Differential expression results

Differential expression analysis results performed by RSEM within the Trinity framework, with "as gene" results shown. A) is the sample correlation matrix for the five samples used in the final cross-comparison. B) shows the relative expression of each differentially expressed contig across all the samples. Note that contigs occurring uniquely in these samples are not included, as detailed in Methods. For both $A$ and $B$, note the areas of the matrix shown in black hues, indicating few measurable differences between-samples 
A)
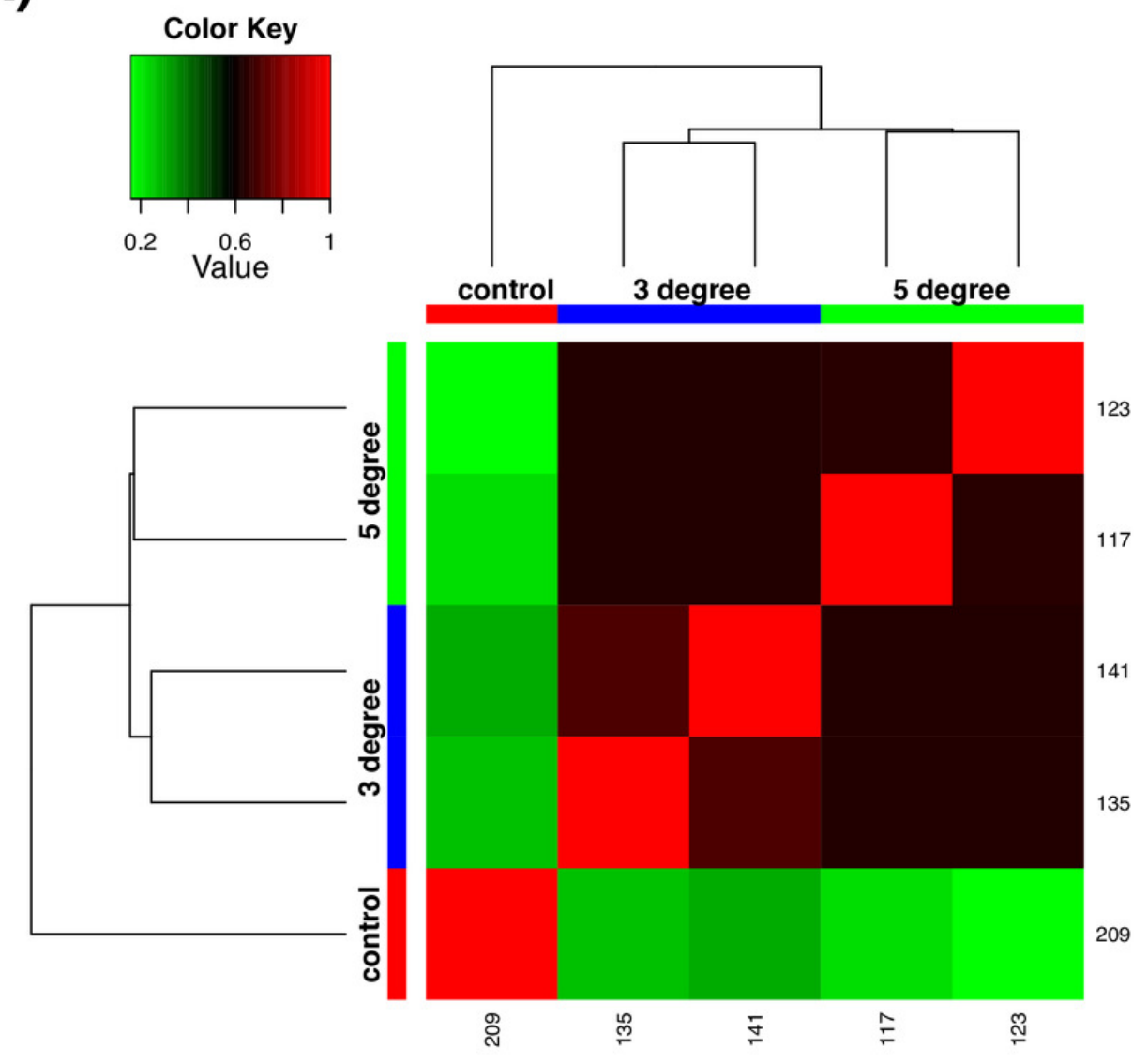

B)
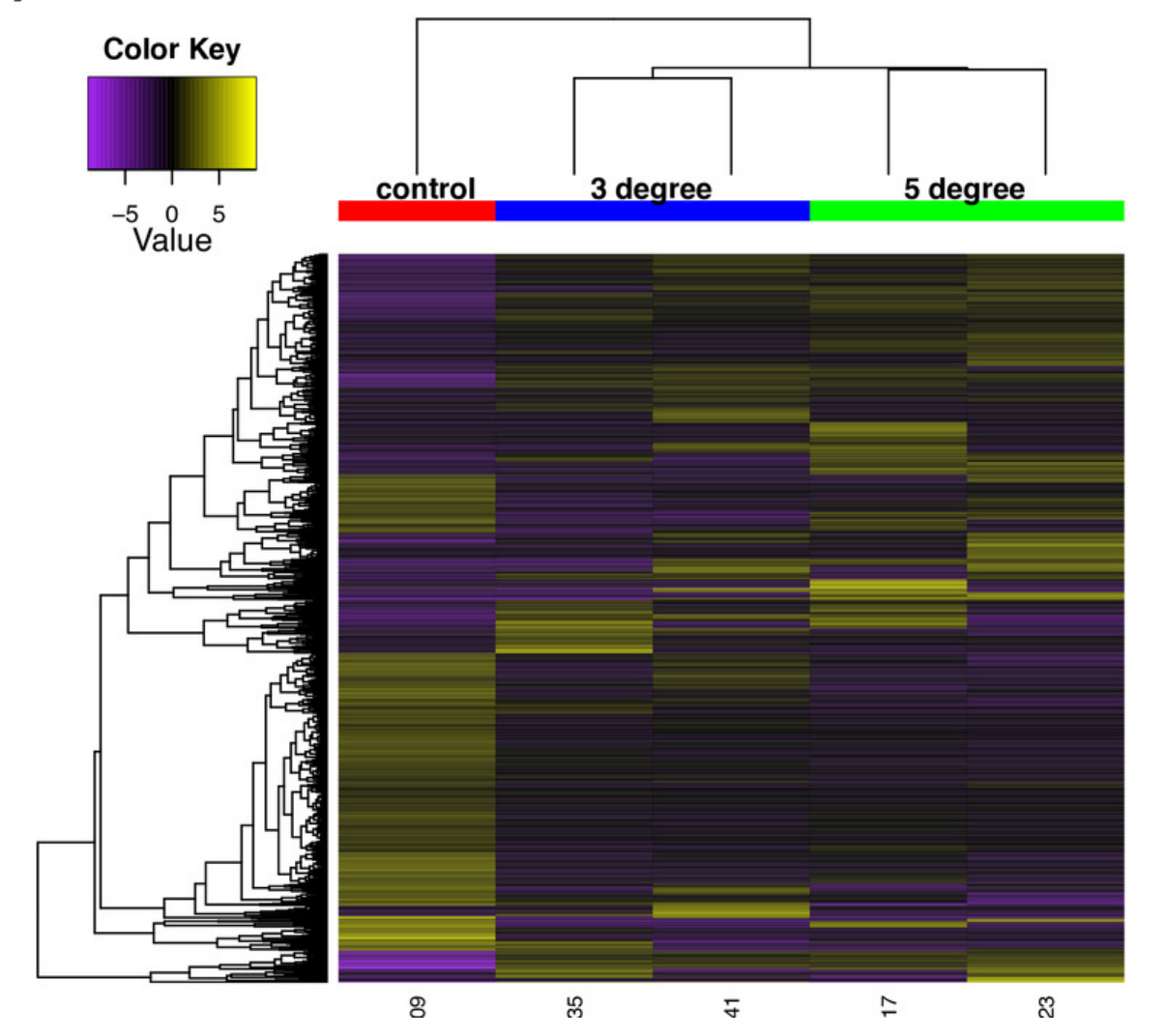

Peer) reviewing PDF | (2019:08:40146:1:1:NEW 25 Sep 2019) 
Figure 3

Significantly differentially represented GO categories

Significantly differentially represented GO categories from contigs up/down regulated at 3 and $5{ }^{\circ} \mathrm{C}$ compared to control sample. A) shows categories from our control vs $3{ }^{\circ} \mathrm{C}$ comparison, while B) shows those from the control vs $5{ }^{\circ} \mathrm{C}$ comparison. Those categories represented in both comparisons are underlined. 
A) Selection of SIgnificant GO Category Distribution Changes, Control vs 3 Degree

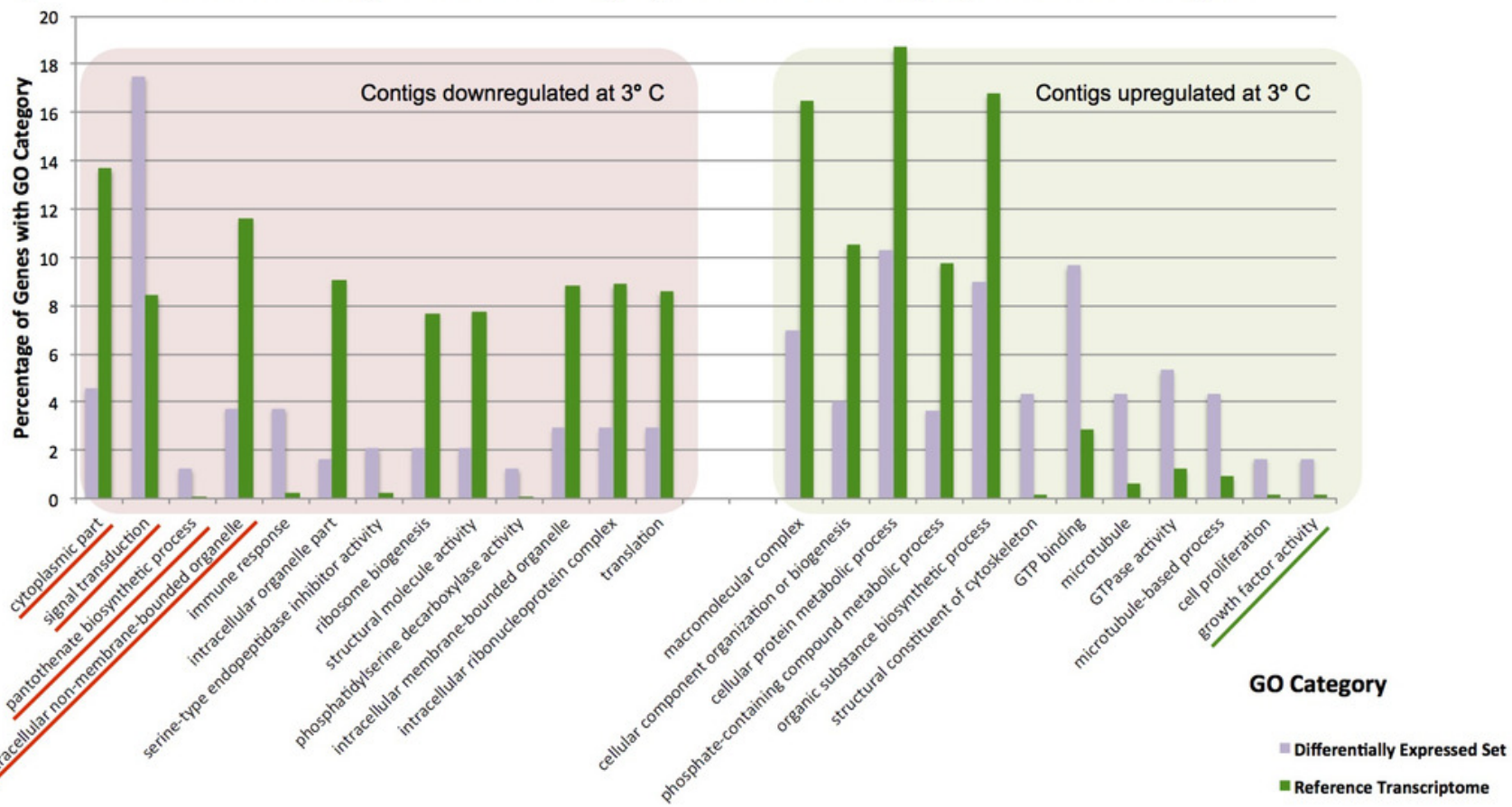

\section{B) Selection of Significant GO Category Distribution Changes, Control vs 5 Degree}
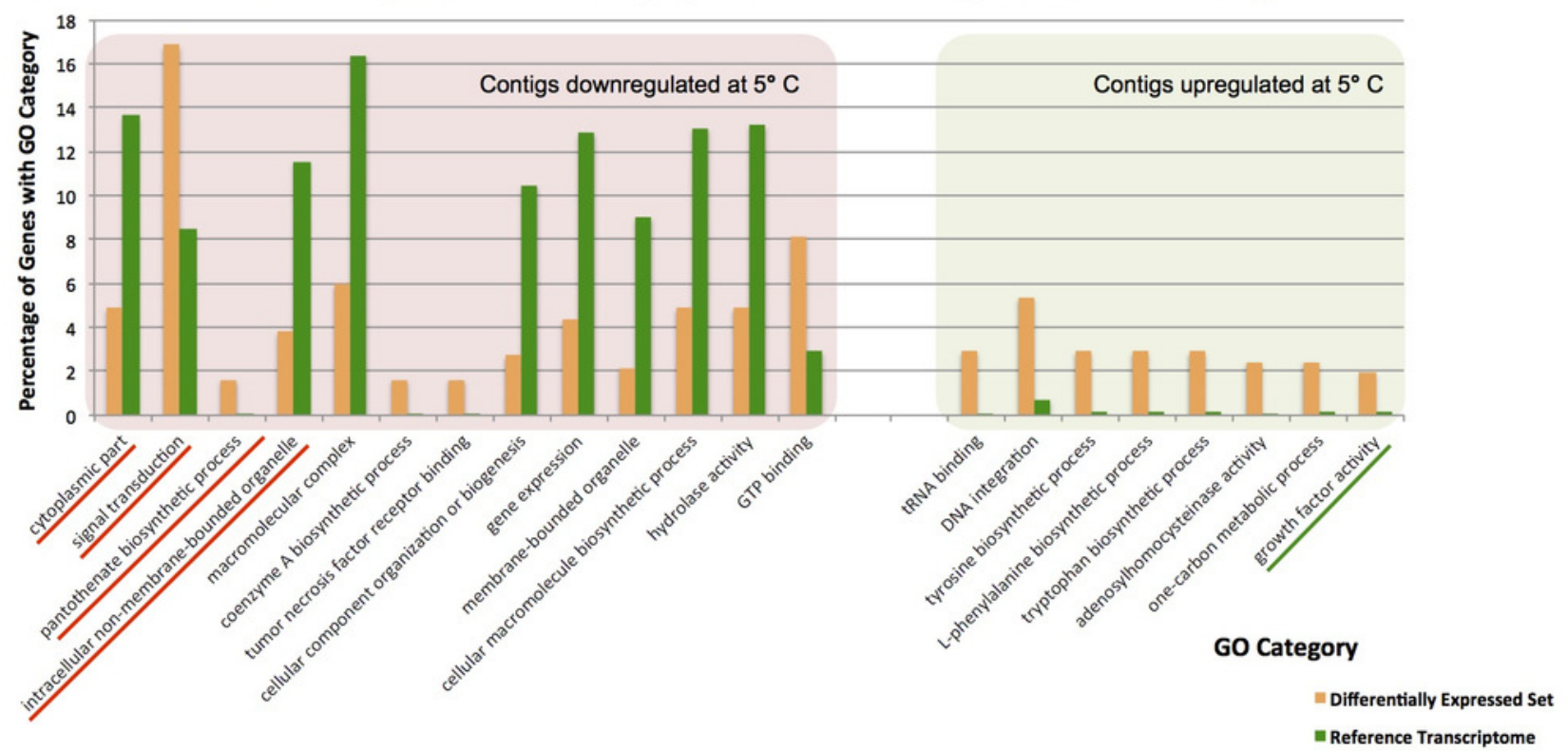


\section{Figure 4}

HSP phylogeny and alignment

A) Maximum likelihood-derived phylogeny (RAXML, $L G+I+G$ ) of HSP70 sequences of known homology, together with novel Isodictya sequences (Names in purple). HSP70 sequences of Antarctic-resident species are bolded. Boxed as indicated on the figure are the HSP70-B, HSP70-A (HSC) and glucose-regulated 78 kDa HSP70 clades. Numbers at base of nodes indicate bootstrap support (as \%ge of 1000 replicates). 5B: Multiple alignment of different HSP70 isoforms found in Isodictya sp. with (inducible) HSP70-B, sequence at top, HSP70-A (non-inducible heat-shock cognate) central, and below, HSP-mt sequences. These are shown alongside sequences from other species, showing the differences in domain content between isoforms. All HSPs have two main domains: the ATPase domain involved in ATP hydrolysis, and the substrate binding domain, which binds extended polypeptides, as shown at the bottom of the figure. Yellow boxes represent signature domains within HSP70 proteins. The $\mathrm{G} / \mathrm{P}$ rich terminal region is prominent in HSPC (HSP-B). The EEVD sequence motif allows the cytoplasmic localisation of HSP and HSC isoforms. Accession numbers as provided in Figure, all sequences are provided, along with alignments, in Supplementary File 6. 


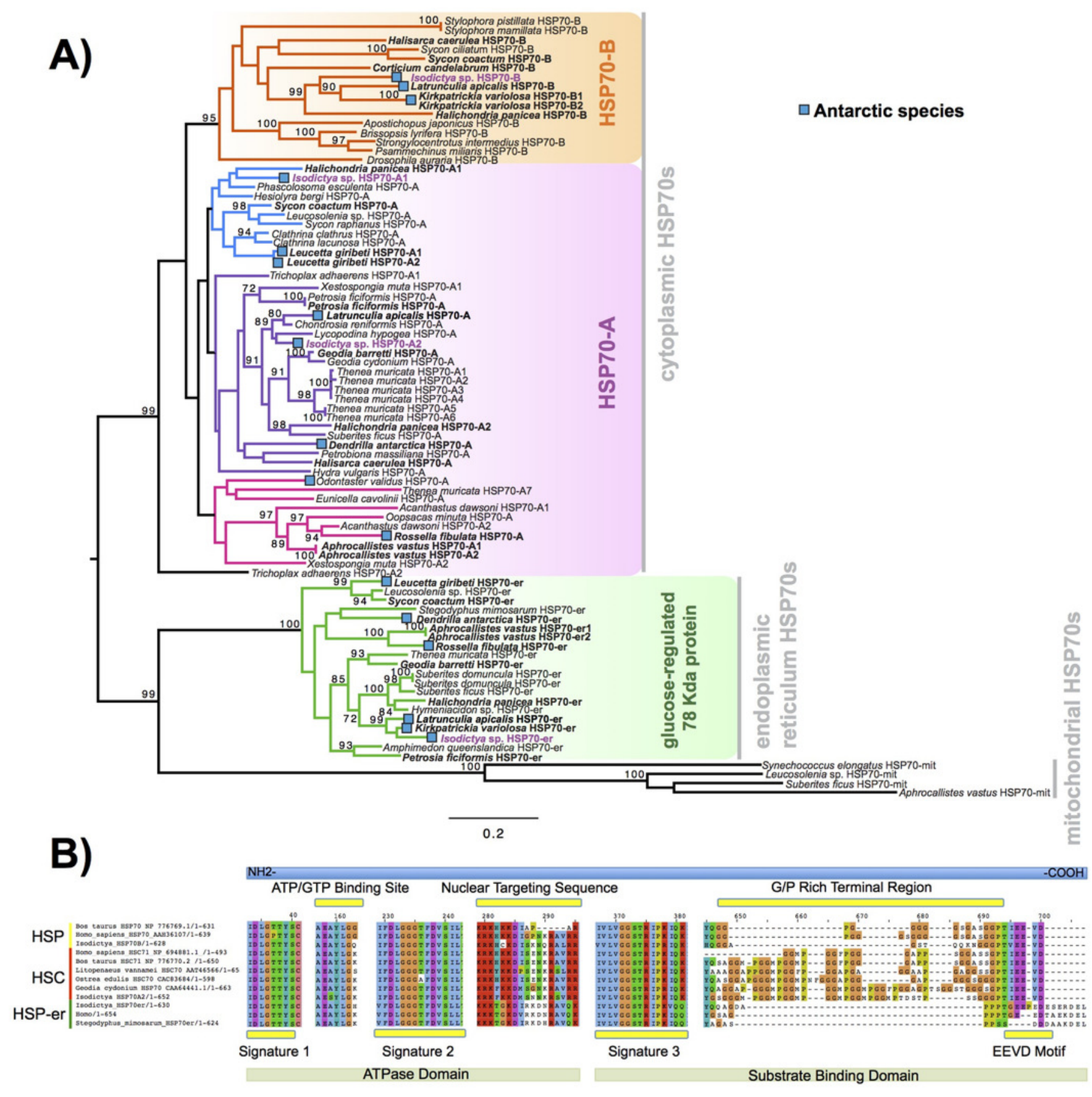




\section{Figure 5}

Ubiquitin pathway recovery

KEGG style map showing recovery of Ubiquitin mediated proteolysis genes in our resource as assessed by bi-directional best blast hit, alongside that of the sequenced genome of Amphimedon queenslandica. Genes noted as present in this resource indicated in green, with those absent in our transcriptome noted in orange if also missing from A. queenslandica (and therefore a possible poriferan absence), or red if absent from our resource only (and therefore a likely true absence). 


\section{Ubiquitin Mediated Proteolysis}

A)

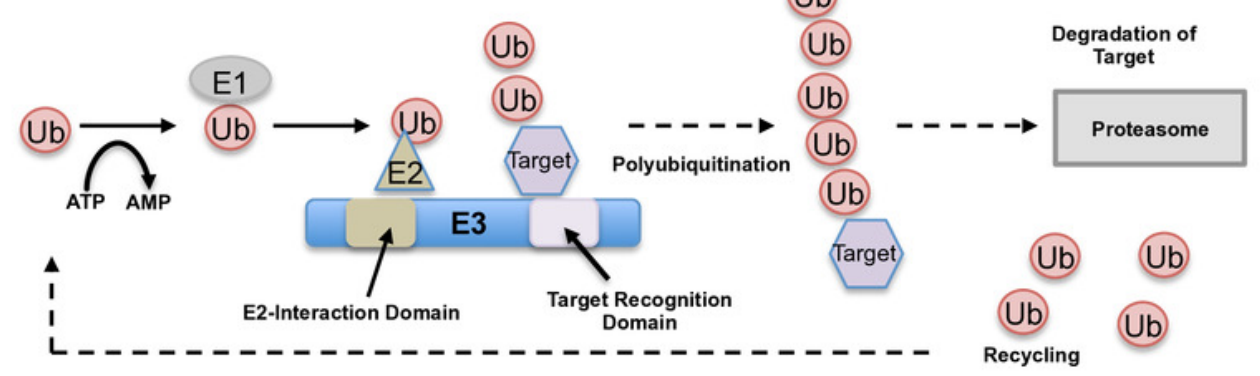

E2: Ubiquitin-conjugating Enzyme

\section{E1: Ubiquitin-activating Enzyme}

\begin{tabular}{|l|l|l|}
\hline UBE UBLE1A UBLE1B UBLE1C \\
\hline
\end{tabular}

\begin{tabular}{|c|c|c|c|c|c|c|c|c|}
\hline UBE2A & UBE2B & UBE2C & UBE2D & UBE2E & UBE2F & UBE2G1 & UBE2G2 & UBE2H \\
\hline UBE2I & UBE2J1 & UBE2J2 & UBE2L3 & UBE2L6 & UBE2M & UBE2N & UBE2O & \\
\hline UBE2Q & UBE2R & UBE2S & UBE2U & UBE2W & UBE2Z & HIP2 & APCLLON & \\
\hline
\end{tabular}

B) E3 (Ubiquitin ligase) Complexes:

HECT type E3

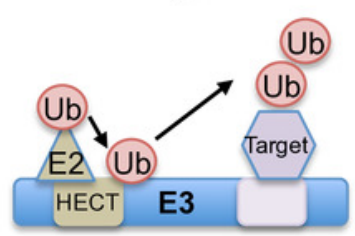

U-box type E3
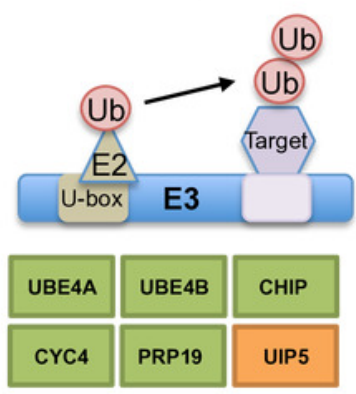

Single RING-finger type E3

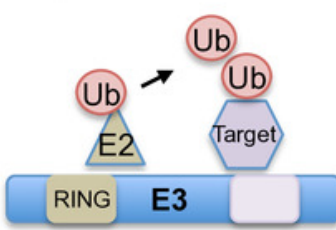

\begin{tabular}{|l|l|l|l|l|}
\hline E6AP & UBE3B & UBE3C & Smurf & Itch \\
\hline WWP1 & WWP2 & TRIP12 & NEDD4 & ARF-BP1 \\
\hline EDD1 & HERC1 & HERC2 & HERC3 & HERC4 \\
\hline
\end{tabular}

\begin{tabular}{|c|c|c|c|c|c|c|}
\hline Mdm2 & CBL & Parkin & SIAH-1 & PML & TRAF6 & MEKK1 \\
\hline COP1 & PIRH2 & ClAPs & PIAS & SYVN & NHLRC1 & AIRE \\
\hline MGRN1 & BRCA1 & FANCL & MID1 & Trim32 & Trim37 \\
\hline
\end{tabular}

Multi subunit RING-finger type E3

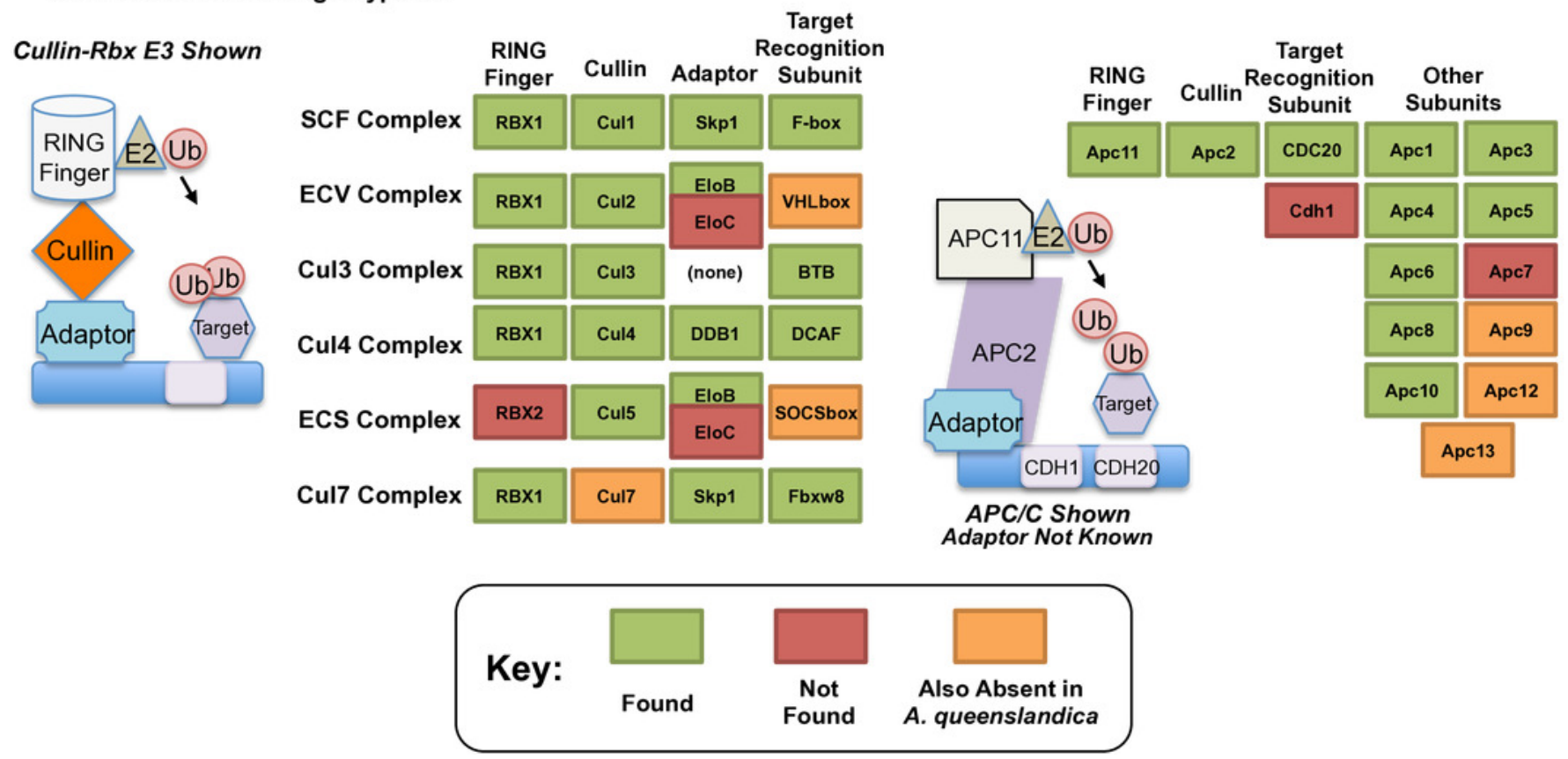




\section{Figure 6}

Figure 6: Alignment and phylogenetic analysis of the AIF sequences found in our transcriptome.

Figure 6: Alignment and phylogenetic analysis of the AIF sequences found in our transcriptome. A) The conserved two EF-hand motifs are indicated in the alignment of several AlF-1 from other invertebrate and vertebrate sequences; b) Phylogenetic tree of the AlF-1 family using the N-J method. Bootstrap values represent the frequency of appearance (expressed as a percentage) of each clade of 1000 bootstrap replicates; c) Percentage amino acid identities between AlF-1 genes from invertebrates and vertebrates. The GenBank accession numbers for the sequences are as follows: Suberites domuncula CAC38780; Acropora digitifera XP015755194; Orbicella faveolata XP020615825; Amphimedon queenslandica XP003387413; Salmo salar AC169994; Mus musculus; Homo sapiens P55008; Bos taurus NP001071547; Sus crofa P81076; Crassostrea gigas NP001292275; Sterechinus neumayeri ACO40483; Haliotis discus ABH10674. 
a.

EFh calcium binding motif EFh calcium binding motif

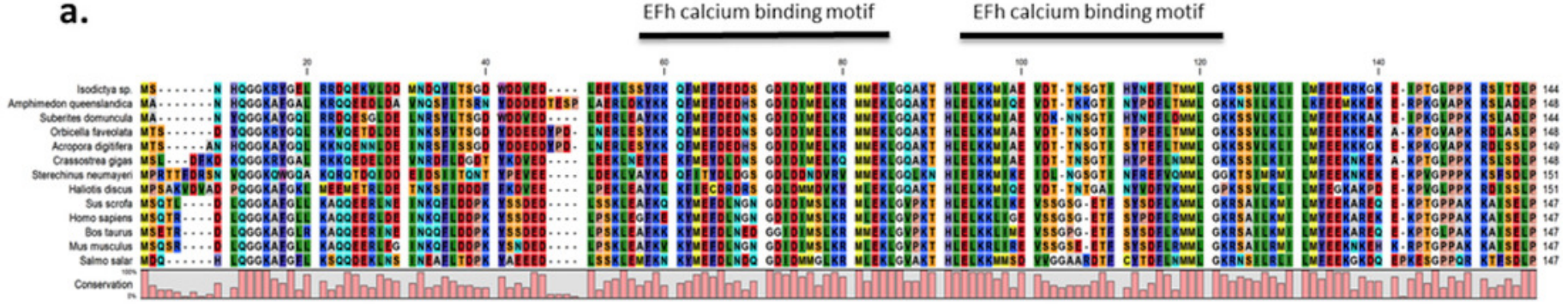

b.

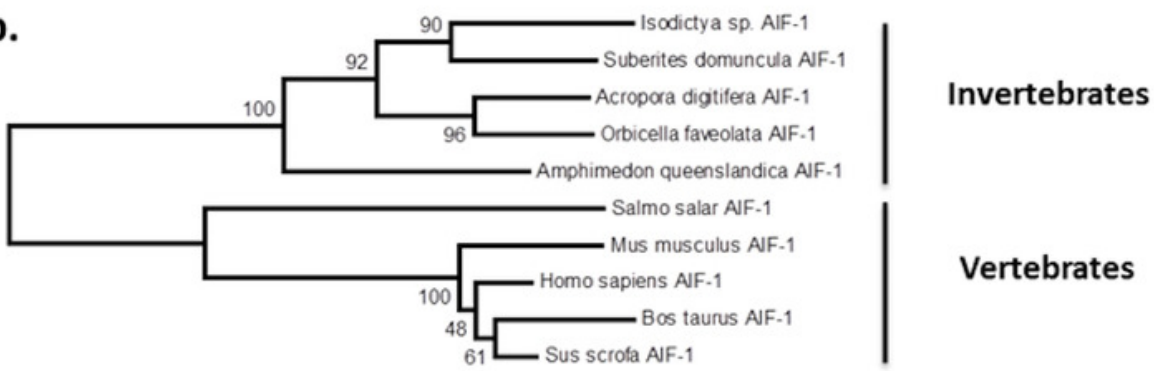

c.

Percentage of identity

\begin{tabular}{|c|c|c|c|c|c|c|c|c|c|c|c|c|c|c|}
\hline & & 1 & 2 & 3 & 4 & 5 & 6 & 7 & 8 & 9 & 10 & 11 & 12 & 13 \\
\hline hodictas sp. & 1 & & 6824 & 83,33 & 75.00 & 73,83 & 70.95 & 48,34 & 56,20 & 50,68 & 52,03 & 50,68 & 40,32 & 48.29 \\
\hline Amphimedon Queenalandica & 2 & 101 & & 72,30 & 72,48 & 73,33 & 63,16 & 47,10 & 53,55 & 51,32 & 53,29 & 51,32 & 50,66 & 51,68 \\
\hline Suberises domunouls & 3 & 120 & 107 & & 77,70 & 76,51 & 70.95 & 50,33 & 56.95 & 51,35 & 52.03 & 51,35 & 49.32 & 50,34 \\
\hline Cobicella taveolats & 4 & 111 & 100 & 115 & & 87,25 & 70,86 & 45,45 & 59,00 & 51,66 & 53,64 & 50,33 & 49,67 & 48,67 \\
\hline Acropora dopltere & 5 & 110 & 110 & 114 & 130 & & $\infty 8.23$ & 46.75 & 59,74 & 51,32 & 52.63 & 50,26 & 40.66 & 50,33 \\
\hline Crastostes pigats & 6 & 105 & $\infty$ & 105 & 107 & 100 & & 53,64 & 59,00 & 54,30 & 56,95 & 53,64 & 52.80 & 50,00 \\
\hline Sterectinus neumayeri & 7 & 73 & 73 & 76 & 70 & 72 & 81 & & 49,67 & 40,13 & 40,13 & 30.92 & 38.10 & 38.56 \\
\hline Haliots decest & 8 & 85 & 83 & 80 & 91 & 92 & $\infty$ & 75 & & 51,32 & 51,32 & 49,34 & 48.03 & 45,10 \\
\hline Sus scrots & ? & 75 & 78 & 76 & 78 & 78 & 82 & 61 & 78 & & 92,88 & $\infty, 48$ & 88,4 & $65 . \pi$ \\
\hline Homo sapiens & 10 & $n$ & 81 & $n$ & 81 & 80 & 86 & 61 & 78 & 138. & & 88,44 & 89.12 & 60,70 \\
\hline Bos tauns & 11 & 75 & 78 & 76 & 76 & $\pi$ & 81 & 50 & 75 & 133 & 130 & & 8200 & 61,07 \\
\hline Mus musculus & 12 & 73 & $n$ & 73 & 75 & 74 & 80 & 58 & 73 & 130 & 131 & 122 & & 63,00 \\
\hline Salmo salar & 13 & 72 & 78 & 74 & 73 & 78 & 75 & 50 & 60 & 98 & 95 & 91 & 94 & \\
\hline
\end{tabular}

Identities 


\section{Table $\mathbf{1}$ (on next page)}

Raw Read Data, Before and After Cleaning 
1

\begin{tabular}{|c|c|c|c|c|c|}
\hline Metric & Control (209) & $\begin{array}{c}3^{\circ} \mathrm{C} \text { Replicate } \mathrm{A} \\
\text { (117) }\end{array}$ & $\begin{array}{c}3^{\circ} \mathrm{C} \text { Replicate B } \\
\text { (123) }\end{array}$ & $\begin{array}{c}5{ }^{\circ} \mathrm{C} \text { Replicate A } \\
\text { (135) }\end{array}$ & $\begin{array}{c}5^{\circ} \mathrm{C} \text { Replicate B } \\
(141)\end{array}$ \\
\hline $\begin{array}{l}\text { Total Read Pairs } \\
\text { (Initial) }\end{array}$ & $25,988,569$ & $28,513,364$ & $26,960,296$ & $25,793,570$ & $26,289,401$ \\
\hline $\begin{array}{l}\text { Total Read Pairs } \\
\text { (After Cleaning) }\end{array}$ & $18,784,882$ & $20,653,864$ & $19,553,789$ & $18,122,106$ & $18,763,103$ \\
\hline $\begin{array}{l}\text { Total Bases in All } \\
\text { Reads (Initial) }\end{array}$ & $5,249,690,938$ & $5,759,699,528$ & $5,445,979,792$ & $5,210,301,140$ & $5,310,459,002$ \\
\hline $\begin{array}{l}\text { Total Bases in All } \\
\text { Reads (After } \\
\text { Cleaning) }\end{array}$ & $3,591,119,834$ & $3,940,343,972$ & $3,742,325,651$ & $3,441,581,533$ & $3,575,958,067$ \\
\hline GC\% (Initial) & 45 & 46 & 45 & 46 & 45 \\
\hline $\begin{array}{l}\text { GC\% (After } \\
\text { Cleaning) }\end{array}$ & 45 & 46 & 44 & 46 & 44 \\
\hline Average Q (Initial) & 35.75 & 35.75 & 35.8 & 35.55 & 35.75 \\
\hline $\begin{array}{l}\text { Average } Q \text { (After } \\
\text { Cleaning) }\end{array}$ & 37.45 & 37.4 & 37.45 & 37.4 & 37.4 \\
\hline $\begin{array}{l}\text { \% less than Q20 } \\
\text { (Initial) }\end{array}$ & 4.55 & 4.55 & 4.55 & 5.05 & 4.7 \\
\hline $\begin{array}{l}\% \text { less than Q20 } \\
\text { (After Cleaning) }\end{array}$ & 0.2 & 0.2 & 0.2 & 0.25 & 0.25 \\
\hline
\end{tabular}

2

3 
Table 2 (on next page)

Statistics, Reference Transcriptome Assembly 
1

\begin{tabular}{|l|l|}
\hline Number of transcripts & 90,188 \\
\hline Number of Trinity 'genes' & 70,844 \\
\hline Total bp in assembly & $59,274,448$ \\
\hline Max contig length (bp) & 19,068 \\
\hline Mean contig length (bp) & 657.23 \\
\hline Median contig length (bp) & 338 \\
\hline \% GC & $43.10 \%$ \\
\hline N20 Contig Length & 2,921 \\
\hline N50 Contig Length & 1,113 \\
\hline \# contigs in N50 & 12,997 \\
\hline Number of transcripts over 1000 bp & 14,633 \\
\hline Transcripts w/ blast hit & 20,607 \\
\hline Transcripts w/ GO term & 12,924 \\
\hline
\end{tabular}

2 
Table 3 (on next page)

The 20 most up/downregulated contigs in each sample cross-comparison 


\begin{tabular}{|c|c|c|c|c|c|}
\hline $\begin{array}{l}\text { Control vs } 3 \\
\text { degrees, } \\
\text { Downregulate } \\
\text { d }\end{array}$ & Annotation & $\begin{array}{l}\text { Control vs } 5 \\
\text { degrees, } \\
\text { downregulate } \\
\text { d }\end{array}$ & Annotation & $\begin{array}{l}3 \text { vs } 5 \\
\text { degrees, } \\
\text { downregulate } \\
\text { d }\end{array}$ & Annotation \\
\hline $\begin{array}{l}\text { TRINITY_DN20177_c1_ } \\
\text { g1 }\end{array}$ & $---\mathrm{NA}---$ & $\begin{array}{l}\text { TRINITY_DN24223_c2 } \\
\text { g2 }\end{array}$ & $\begin{array}{l}\text { PLANT CADMIUM } \\
\text { RESISTANCE 3-like }\end{array}$ & $\begin{array}{l}\text { TRINITY_DN23764_C0_ } \\
\text { g2 }\end{array}$ & $\begin{array}{l}\text { polyadenylate-binding - } \\
\text { interacting 1-like }\end{array}$ \\
\hline $\begin{array}{l}\text { TRINITY_DN33508_c0_ } \\
\text { g1 }\end{array}$ & $---N A---$ & $\begin{array}{l}\text { TRINITY_DN20177_c1_ } \\
\text { g1 }\end{array}$ & ---NA--- & $\begin{array}{l}\text { TRINITY_DN24223_c2 } \\
\text { g2 }\end{array}$ & $\begin{array}{l}\text { PLANT CADMIUM } \\
\text { RESISTANCE 3-like }\end{array}$ \\
\hline $\begin{array}{l}\text { TRINITY_DN45390_c0_ } \\
\text { g1 }\end{array}$ & $---N A--$ & $\begin{array}{l}\text { TRINITY_DN8570_c0_g } \\
1\end{array}$ & hypothetical protein & $\begin{array}{l}\text { TRINITY_DN12683_C0_ } \\
\text { g1 }\end{array}$ & $\begin{array}{l}\text { allograft inflammatory } \\
\text { factor } 1\end{array}$ \\
\hline $\begin{array}{l}\text { TRINITY_DN33508_c0_ } \\
\text { g4 }\end{array}$ & $---N A--$ & $\begin{array}{l}\text { TRINITY_DN32712_C4_- } \\
\text { g3 }\end{array}$ & ---NA--- & $\begin{array}{l}\text { TRINITY_DN6163_c0_g } \\
2\end{array}$ & $\begin{array}{l}\text { ubiquitin carboxyl- } \\
\text { terminal hydrolase } \\
\text { isozyme L3-like }\end{array}$ \\
\hline $\begin{array}{l}\text { TRINITY_DN35469_c0_ } \\
\text { g1 }\end{array}$ & $\begin{array}{l}\text { soluble calcium-activated } \\
\text { nucleotidase } 1 \text { isoform } \\
\mathrm{X} 1\end{array}$ & $\begin{array}{l}\text { TRINITY_DN24027_c0_ } \\
\text { g1 }\end{array}$ & ---NA--- & $\begin{array}{l}\text { TRINITY_DN23190_c0_ } \\
\text { g1 }\end{array}$ & $---N A---$ \\
\hline $\begin{array}{l}\text { TRINITY_DN35123_c0_ } \\
\text { g3 }\end{array}$ & $---N A---$ & $\begin{array}{l}\text { TRINITY_DN40223_CO_ } \\
\text { g1 }\end{array}$ & ---NA--- & $\begin{array}{l}\text { TRINITY_DN24468_c0_ } \\
\text { g2 }\end{array}$ & ---NA--- \\
\hline $\begin{array}{l}\text { TRINITY_DN19331_C1_- } \\
\text { g1 }\end{array}$ & hypothetical protein & $\begin{array}{l}\text { TRINITY_DN8786_C0_g } \\
\text { The }\end{array}$ & oxysterol-binding 1-like & $\begin{array}{l}\text { TRINITY_DN30615_c2 } \\
\text { g9 }\end{array}$ & ---NA--- \\
\hline $\begin{array}{l}\text { TRINITY_DN24815_C0_ } \\
\text { g1 }\end{array}$ & ---NA--- & $\begin{array}{l}\text { TRINITY_DN35469_C0_ } \\
\text { g1 }\end{array}$ & $\begin{array}{l}\text { soluble calcium-activated } \\
\text { nucleotidase } 1 \text { isoform } \\
\mathrm{X} 1\end{array}$ & $\begin{array}{l}\text { TRINITY_DN8356_c0_g } \\
2\end{array}$ & $\begin{array}{l}\text { ubiquitin-conjugating } \\
\text { enzyme E2 K-like }\end{array}$ \\
\hline $\begin{array}{l}\text { TRINITY_DN8271_c0_g } \\
1\end{array}$ & $---\mathrm{NA}---$ & $\begin{array}{l}\text { TRINITY_DN45390_C0_ } \\
\text { g1 }\end{array}$ & $---\mathrm{NA}---$ & $\begin{array}{l}\text { TRINITY_DN26078_c0_ } \\
\text { g2 }\end{array}$ & $\begin{array}{l}\text { COMM domain- } \\
\text { containing 8-like }\end{array}$ \\
\hline $\begin{array}{l}\text { TRINITY_DN31187_C0_ } \\
\text { g1 }\end{array}$ & $---N A---$ & $\begin{array}{l}\text { TRINITY_DN33246_c0_ } \\
\text { g3 }\end{array}$ & $---\mathrm{NA}---$ & $\begin{array}{l}\text { TRINITY_DN58418_c0_ } \\
\text { g1 }\end{array}$ & nucleoporin GLE1-like \\
\hline $\begin{array}{l}\text { TRINITY_DN49200_c0_ } \\
\text { g1 }\end{array}$ & $---\mathrm{NA}---$ & $\begin{array}{l}\text { TRINITY_DN33508_c0_ } \\
\text { g4 }\end{array}$ & $---N A--$ & $\begin{array}{l}\text { TRINITY_DN35203_c0_ } \\
\text { g2 }\end{array}$ & $---\mathrm{NA}---$ \\
\hline $\begin{array}{l}\text { TRINITY_DN33462_c0_ } \\
\text { g1 }\end{array}$ & $---\mathrm{NA}---$ & $\begin{array}{l}\text { TRINITY_DN11747_C0_ } \\
\text { g1 }\end{array}$ & \multicolumn{3}{|l|}{ hypothetical protein, partial } \\
\hline $\begin{array}{l}\text { TRINITY_DN4804_c0_g } \\
2\end{array}$ & $\begin{array}{l}\text { hypothetical protein } \\
\text { TRIADDRAFT_59764 }\end{array}$ & $\begin{array}{l}\text { TRINITY_DN24815_c0_ } \\
\text { g1 }\end{array}$ & $---\mathrm{NA}---$ & & \\
\hline $\begin{array}{l}\text { TRINITY_DN23863_c0_ } \\
\text { g1 }\end{array}$ & $---N A---$ & $\begin{array}{l}\text { TRINITY_DN24481_C0_ } \\
\text { g1 }\end{array}$ & $---\mathrm{NA}---$ & & \\
\hline $\begin{array}{l}\text { TRINITY_DN33246_C0_ } \\
\text { g3 }\end{array}$ & $---\mathrm{NA}---$ & $\begin{array}{l}\text { TRINITY_DN30570_C0_ } \\
\text { g1 }\end{array}$ & \multicolumn{2}{|l|}{ replicase poly } & \\
\hline $\begin{array}{l}\text { TRINITY_DN30570_C0_ } \\
\text { g1 }\end{array}$ & $---\mathrm{NA}---$ & $\begin{array}{l}\text { TRINITY_DN35123_c0_ } \\
\text { g3 }\end{array}$ & $---\mathrm{NA}---$ & & \\
\hline $\begin{array}{l}\text { TRINITY_DN26078_c0_ } \\
\text { g1 }\end{array}$ & $\begin{array}{l}\text { COMM domain- } \\
\text { containing 8-like }\end{array}$ & $\begin{array}{l}\text { TRINITY_DN59119_C0_ } \\
\text { g1 }\end{array}$ & ---NA--- & & \\
\hline $\begin{array}{l}\text { TRINITY_DN12307_c0_ } \\
\text { g1 }\end{array}$ & $\begin{array}{l}\text { PREDICTED: } \\
\text { uncharacterized protein }\end{array}$ & $\begin{array}{l}\text { TRINITY_DN13825_c0_ } \\
\text { g1 }\end{array}$ & \multicolumn{3}{|c|}{ endoplasmic reticulum-Golgi intermediate compartment 3-like } \\
\hline $\begin{array}{l}\text { TRINITY_DN36675_C0_ } \\
\text { g1 }\end{array}$ & $---N A---$ & $\begin{array}{l}\text { TRINITY_DN26662_C0_ } \\
\text { g1 }\end{array}$ & \multicolumn{3}{|l|}{ hypothetical protein crov191 } \\
\hline $\begin{array}{l}\text { Control vs } 3 \\
\text { degrees, } \\
\text { Upregulated }\end{array}$ & Annotation & $\begin{array}{l}\text { Control vs } 5 \\
\text { degrees, } \\
\text { Upregulated }\end{array}$ & Annotation & $\begin{array}{l}3 \text { vs } 5 \\
\text { degrees, } \\
\text { upregulated }\end{array}$ & Annotation \\
\hline $\begin{array}{l}\text { TRINITY_DN24284_CO_ } \\
\text { g3 }\end{array}$ & $\begin{array}{l}\text { hypothetical protein } \\
\text { BRAFLDRAFT_114823 }\end{array}$ & $\begin{array}{l}\text { TRINITY_DN24284_C0_ } \\
\text { g3 }\end{array}$ & $\begin{array}{l}\text { hypothetical protein } \\
\text { BRAFLDRAFT_114823 }\end{array}$ & $\begin{array}{l}\text { TRINITY_DN33462_C0_ } \\
\text { g1 }\end{array}$ & $---N A---$ \\
\hline
\end{tabular}




\begin{tabular}{|c|c|c|c|c|c|}
\hline $\begin{array}{l}\text { TRINITY_DN44573_c0_ } \\
\text { g1 }\end{array}$ & hypothetical protein & $\begin{array}{l}\text { TRINITY_DN24223_C2 } \\
\text { g1 }\end{array}$ & $\begin{array}{l}\text { PLANT CADMIUM } \\
\text { RESISTANCE 3-like }\end{array}$ & $\begin{array}{l}\text { TRINITY_DN53922_C0_ } \\
\text { g3 }\end{array}$ & $\begin{array}{l}\text { inactive peptidyl-prolyl } \\
\text { cis-trans isomerase } \\
\text { FKBP6-like }\end{array}$ \\
\hline $\begin{array}{l}\text { TRINITY_DN18944_C0_ } \\
\text { g2 }\end{array}$ & $40 \mathrm{~S}$ ribosomal $\mathrm{S} 13$ & $\begin{array}{l}\text { TRINITY_DN44573_c0_ } \\
\text { g1 }\end{array}$ & hypothetical protein & $\begin{array}{l}\text { TRINITY_DN23764_c0_ } \\
\text { g1 }\end{array}$ & $\begin{array}{l}\text { polyadenylate-binding - } \\
\text { interacting } 1 \text {-like }\end{array}$ \\
\hline $\begin{array}{l}\text { TRINITY_DN33508_c0_ } \\
\text { g2 }\end{array}$ & $---\mathrm{NA}---$ & $\begin{array}{l}\text { TRINITY_DN22854_C0_ } \\
\text { g2 }\end{array}$ & $\begin{array}{l}\text { PREDICTED: } \\
\text { tetraspanin-7-like }\end{array}$ & $\begin{array}{l}\text { TRINITY_DN58083_C0_ } \\
\text { g1 }\end{array}$ & $---N A---$ \\
\hline $\begin{array}{l}\text { TRINITY_DN24223_c2_- } \\
\text { g1 }\end{array}$ & $\begin{array}{l}\text { PLANT CADMIUM } \\
\text { RESISTANCE 3-like }\end{array}$ & $\begin{array}{l}\text { TRINITY_DN8786_c0_g } \\
2\end{array}$ & oxysterol-binding 1-like & $\begin{array}{l}\text { TRINITY_DN23863_C0_ } \\
\text { g1 }\end{array}$ & ---NA--- \\
\hline $\begin{array}{l}\text { TRINITY_DN34845_c4_- } \\
\text { g12 }\end{array}$ & $---N A---$ & $\begin{array}{l}\text { TRINITY_DN29050_c0_ } \\
\text { g1 }\end{array}$ & \multicolumn{2}{|l|}{ hypothetical protein } & \\
\hline $\begin{array}{l}\text { TRINITY_DN34845_C4_ } \\
\text { g3 }\end{array}$ & $---N A---$ & $\begin{array}{l}\text { TRINITY_DN18944_C0_ } \\
\text { g2 }\end{array}$ & \multicolumn{2}{|l|}{$40 \mathrm{~S}$ ribosomal $\mathrm{S} 13$} & \\
\hline $\begin{array}{l}\text { TRINITY_DN22854_CO_ } \\
\text { g2 }\end{array}$ & $\begin{array}{l}\text { PREDICTED: } \\
\text { tetraspanin-7-like }\end{array}$ & $\begin{array}{l}\text { TRINITY_DN53805_C0_ } \\
\text { g1 }\end{array}$ & \multicolumn{3}{|c|}{ PREDICTED: uncharacterized protein } \\
\hline $\begin{array}{l}\text { TRINITY_DN34845_C4_ } \\
\text { g9 }\end{array}$ & $---N A---$ & $\begin{array}{l}\text { TRINITY_DN30712_C0_ } \\
\text { g1 }\end{array}$ & $---N A---$ & & \\
\hline $\begin{array}{l}\text { TRINITY_DN22240_c0_ } \\
\text { g4 }\end{array}$ & $---\mathrm{NA}---$ & $\begin{array}{l}\text { TRINITY_DN58083_C0_ } \\
\text { g1 }\end{array}$ & $---N A---$ & & \\
\hline $\begin{array}{l}\text { TRINITY_DN34845_C4_ } \\
\text { g10 }\end{array}$ & $---\mathrm{NA}---$ & $\begin{array}{l}\text { TRINITY_DN26231_C0_ } \\
\text { g4 }\end{array}$ & \multicolumn{3}{|c|}{ dolichyl-diphosphooligosaccharide-- glycosyltransferase $48 \mathrm{kDa}$ subunit-like } \\
\hline $\begin{array}{l}\text { TRINITY_DN44814_C0_ } \\
\text { g1 }\end{array}$ & $---\mathrm{NA}---$ & $\begin{array}{l}\text { TRINITY_DN27017_C0_ } \\
\text { g1 }\end{array}$ & $---N A---$ & & \\
\hline $\begin{array}{l}\text { TRINITY_DN26511_C0_ } \\
\text { g1 }\end{array}$ & hypothetical protein & $\begin{array}{l}\text { TRINITY_DN34845_c4_ } \\
\text { g10 }\end{array}$ & $---\mathrm{NA}---$ & & \\
\hline $\begin{array}{l}\text { TRINITY_DN34845_c4_ } \\
\text { g4 }\end{array}$ & $---N A---$ & $\begin{array}{l}\text { TRINITY_DN24395_C0_ } \\
\text { g1 }\end{array}$ & \multicolumn{2}{|l|}{ heat shock 70 B2-like } & \\
\hline $\begin{array}{l}\text { TRINITY_DN1002_c0_g } \\
1\end{array}$ & predicted protein & $\begin{array}{l}\text { TRINITY_DN34845_C4_ } \\
\text { g4 }\end{array}$ & ---NA--- & & \\
\hline $\begin{array}{l}\text { TRINITY_DN23682_c0_ } \\
\text { g2 }\end{array}$ & $---\mathrm{NA}---$ & $\begin{array}{l}\text { TRINITY_DN34845_c4_ } \\
\text { g12 }\end{array}$ & $---\mathrm{NA}---$ & & \\
\hline $\begin{array}{l}\text { TRINITY_DN26231_C0_ } \\
\text { g4 }\end{array}$ & $\begin{array}{l}\text { dolichyl- } \\
\text { diphosphooligosaccharid } \\
\text { e-- glycosyltransferase } \\
48 \text { kDa subunit-like }\end{array}$ & $\begin{array}{l}\text { TRINITY_DN34845_c4_ } \\
\text { g3 }\end{array}$ & $---N A---$ & & \\
\hline $\begin{array}{l}\text { TRINITY_DN2258_c0_g } \\
\text { T }\end{array}$ & $40 \mathrm{~S}$ ribosomal S25 & $\begin{array}{l}\text { TRINITY_DN22240_c0_ } \\
\text { g4 }\end{array}$ & $---N A---$ & & \\
\hline $\begin{array}{l}\text { TRINITY_DN30873_C1__ } \\
\text { g2 }\end{array}$ & $---\mathrm{NA}---$ & $\begin{array}{l}\text { TRINITY_DN26511_c0_ } \\
\text { g1 }\end{array}$ & $---N A---$ & & \\
\hline $\begin{array}{l}\text { TRINITY_DN20209_C0_ } \\
\text { g1 }\end{array}$ & $---\mathrm{NA}---$ & $\begin{array}{l}\text { TRINITY_DN34845_c4_ } \\
\text { g9 }\end{array}$ & $---N A---$ & & \\
\hline
\end{tabular}


Table 4 (on next page)

Manually identified target genes 


\begin{tabular}{|c|c|c|c|c|c|}
\hline Target gene approach & & & & & \\
\hline $\begin{array}{l}\text { Control vs } 3 \text { degrees, } \\
\text { Downregulated }\end{array}$ & Annotation & $\begin{array}{l}\text { Control vs } 5 \text { degrees, } \\
\text { downregulated }\end{array}$ & Annotation & $\begin{array}{l}3 \text { vs } 5 \text { degrees, } \\
\text { downregulated }\end{array}$ & Annotation \\
\hline $\begin{array}{l}\text { TRINITY_DN49841_c0_ } \\
\text { g3_i1 }\end{array}$ & $\begin{array}{l}\text { tumor necrosis factor } \\
\text { ligand superfamily } \\
\text { member } 15\end{array}$ & $\begin{array}{l}\text { TRINITY_DN49841_c0_ } \\
\text { g3_i1 }\end{array}$ & $\begin{array}{l}\text { tumor necrosis factor } \\
\text { ligand superfamily } \\
\text { member } 15\end{array}$ & $\begin{array}{l}\text { TRINITY_DN23764_c0_ } \\
\text { g2 }\end{array}$ & $\begin{array}{l}\text { polyadenylate-binding - } \\
\text { interacting 1-like }\end{array}$ \\
\hline $\begin{array}{l}\text { TRINITY_DN49577_c0_ } \\
\text { g1_11 }\end{array}$ & $\begin{array}{l}\text { mesoderm development } \\
\text { candidate } 1 \text {-like }\end{array}$ & $\begin{array}{l}\text { TRINITY_DN49577_c0_ } \\
\text { g1_i1 }\end{array}$ & $\begin{array}{l}\text { mesoderm development } \\
\text { candidate 1-like }\end{array}$ & $\begin{array}{l}\text { TRINITY_DN24223_c2 } \\
\text { g2 }\end{array}$ & $\begin{array}{l}\text { PLANT CADMIUM } \\
\text { RESISTANCE 3-like }\end{array}$ \\
\hline $\begin{array}{l}\text { TRINITY_DN34885_c0_ } \\
\text { g2_i2 }\end{array}$ & $\begin{array}{l}\text { neurogenic locus notch } \\
\text { homolog 1-like }\end{array}$ & $\begin{array}{l}\text { TRINITY_DN34885_c0_ } \\
\text { g2_i2 }\end{array}$ & $\begin{array}{l}\text { neurogenic locus notch } \\
\text { homolog } 1 \text {-like }\end{array}$ & $\begin{array}{l}\text { TRINITY_DN12683_c0_ } \\
\text { g1 }\end{array}$ & $\begin{array}{l}\text { allograft inflammatory } \\
\text { factor } 1\end{array}$ \\
\hline $\begin{array}{l}\text { TRINITY_DN28743_c0_ } \\
\text { g1_i1 }\end{array}$ & $\begin{array}{l}\text { E3 ubiquitin- ligase } \\
\text { TRIM71-like }\end{array}$ & $\begin{array}{l}\text { TRINITY_DN28743_c0_ } \\
\text { g1_i1 }\end{array}$ & $\begin{array}{l}\text { E3 ubiquitin- ligase } \\
\text { TRIM71-like }\end{array}$ & $\begin{array}{l}\text { TRINITY_DN6163_c0_g } \\
2\end{array}$ & $\begin{array}{l}\text { ubiquitin carboxyl- } \\
\text { terminal hydrolase } \\
\text { isozyme L3-like }\end{array}$ \\
\hline $\begin{array}{l}\text { TRINITY_DN28248_c0_ } \\
\text { g1_i1 }\end{array}$ & ribosome-binding 1-like & $\begin{array}{l}\text { TRINITY_DN33363_c1_ } \\
\text { g1_i1 }\end{array}$ & $\begin{array}{l}\text { G2 M phase-specific E3 } \\
\text { ubiquitin- ligase- partial }\end{array}$ & $\begin{array}{l}\text { TRINITY_DN8356_c0_g } \\
2\end{array}$ & $\begin{array}{l}\text { ubiquitin-conjugating } \\
\text { enzyme E2 K-like }\end{array}$ \\
\hline $\begin{array}{l}\text { TRINITY_DN30424_c0_ } \\
\text { g1_i1 }\end{array}$ & $\begin{array}{l}\text { delta and Notch-like } \\
\text { epidermal growth factor- } \\
\text { related receptor-like }\end{array}$ & $\begin{array}{l}\text { TRINITY_DN28248_c0_ } \\
\text { g1_i1 }\end{array}$ & ribosome-binding 1-like & $\begin{array}{l}\text { TRINITY_DN26078_c0_ } \\
\text { g2 }\end{array}$ & $\begin{array}{l}\text { COMM domain- } \\
\text { containing 8-like }\end{array}$ \\
\hline $\begin{array}{l}\text { TRINITY_DN31499_c1_ } \\
\text { g3_i1 }\end{array}$ & calmodulin isoform $\mathrm{X} 1$ & $\begin{array}{l}\text { TRINITY_DN4806_c0_g } \\
\text { 1_i1 }\end{array}$ & $\begin{array}{l}\text { polycomb group RING } \\
\text { finger } 1 \text {-like }\end{array}$ & $\begin{array}{l}\text { TRINITY_DN58418_c0_ } \\
\text { g1 }\end{array}$ & nucleoporin GLE1-like \\
\hline $\begin{array}{l}\text { TRINITY_DN29988_c0_ } \\
\text { g1_i1 }\end{array}$ & $\begin{array}{l}\text { TGF-beta receptor type- } \\
\text { 1-like }\end{array}$ & $\begin{array}{l}\text { TRINITY_DN30424_C0_ } \\
\text { g1_i1 }\end{array}$ & \multicolumn{2}{|c|}{$\begin{array}{l}\text { delta and Notch-like epidermal growth factor-related } \\
\text { receptor-like }\end{array}$} & \\
\hline $\begin{array}{l}\text { TRINITY_DN35391_c8_ } \\
\text { g6_i2 }\end{array}$ & $\begin{array}{l}\text { TNF receptor-associated } \\
\text { factor } 5 \text {-like }\end{array}$ & $\begin{array}{l}\text { TRINITY_DN31499_c1_ } \\
\text { g3_i1 }\end{array}$ & calmodulin isoform $\mathrm{X} 1$ & & \\
\hline $\begin{array}{l}\text { TRINITY_DN29288_c0_ } \\
\text { g1_i1 }\end{array}$ & $\begin{array}{l}\text { G- coupled receptor } 161- \\
\text { like }\end{array}$ & $\begin{array}{l}\text { TRINITY_DN35391_c8_ } \\
\text { g6_i2 }\end{array}$ & $\begin{array}{l}\text { TNF receptor-associated } \\
\text { factor } 5 \text {-like }\end{array}$ & & \\
\hline $\begin{array}{l}\text { TRINITY_DN54189_c0_ } \\
\text { g2_i1 }\end{array}$ & $\begin{array}{l}\text { probable G- coupled } \\
\text { receptor } 157\end{array}$ & $\begin{array}{l}\text { TRINITY_DN29288_c0_ } \\
\text { g1_i1 }\end{array}$ & $\begin{array}{l}\text { G- coupled receptor 161- } \\
\text { like }\end{array}$ & & \\
\hline & & $\begin{array}{l}\text { TRINITY_DN54189_c0_ } \\
\text { g2_i1 }\end{array}$ & $\begin{array}{l}\text { probable G- coupled } \\
\text { receptor } 157\end{array}$ & & \\
\hline $\begin{array}{l}\text { Control vs } 3 \text { degrees, } \\
\text { Upregulated }\end{array}$ & Annotation & $\begin{array}{l}\text { Control vs } 5 \text { degrees, } \\
\text { Upregulated }\end{array}$ & Annotation & $\begin{array}{l}3 \text { vs } 5 \text { degrees, } \\
\text { upregulated }\end{array}$ & Annotation \\
\hline $\begin{array}{l}\text { TRINITY_DN12683_c0_ } \\
\text { g1_i1 }\end{array}$ & $\begin{array}{l}\text { allograft inflammatory } \\
\text { factor } 1\end{array}$ & $\begin{array}{l}\text { TRINITY_DN25219_c0_ } \\
\text { g1_i1 }\end{array}$ & ubiquitin- ligase E3A-like & $\begin{array}{l}\text { TRINITY_DN53922_c0_ } \\
\text { g3 }\end{array}$ & $\begin{array}{l}\text { inactive peptidyl-prolyl } \\
\text { cis-trans isomerase } \\
\text { FKBP6-like }\end{array}$ \\
\hline $\begin{array}{l}\text { TRINITY_DN27456_c0_ } \\
\text { g1_i1 }\end{array}$ & tolloid 1 & $\begin{array}{l}\text { TRINITY_DN40009_c0_ } \\
\text { g1_i1 }\end{array}$ & $\begin{array}{l}\text { transcription factor Sox- } \\
\text { 2-like }\end{array}$ & $\begin{array}{l}\text { TRINITY_DN23764_c0_ } \\
\text { g1 }\end{array}$ & $\begin{array}{l}\text { polyadenylate-binding - } \\
\text { interacting } 1 \text {-like }\end{array}$ \\
\hline $\begin{array}{l}\text { TRINITY_DN25219_c0_ } \\
\text { g1_i1 }\end{array}$ & ubiquitin- ligase E3A-like & $\begin{array}{l}\text { TRINITY_DN24395_c0_ } \\
\text { g1_i1 }\end{array}$ & heat shock 70 B2-like & & \\
\hline $\begin{array}{l}\text { TRINITY_DN40009_c0_ } \\
\text { g1_i1 }\end{array}$ & $\begin{array}{l}\text { transcription factor Sox- } \\
\text { 2-like }\end{array}$ & $\begin{array}{l}\text { TRINITY_DN33837_c0_ } \\
\text { g3_i1 }\end{array}$ & $\begin{array}{l}\text { TNF receptor-associated } \\
\text { factor } 5 \text {-like }\end{array}$ & & \\
\hline $\begin{array}{l}\text { TRINITY_DN24395_c0_ } \\
\text { g1_i1 }\end{array}$ & heat shock 70 B2-like & $\begin{array}{l}\text { TRINITY_DN34897_c0_ } \\
\text { g1_i1 }\end{array}$ & tolloid 2 & & \\
\hline $\begin{array}{l}\text { TRINITY_DN16789_c0_ } \\
\text { g1_i1 }\end{array}$ & indian hedgehog & $\begin{array}{l}\text { TRINITY_DN29751_c0_ } \\
\text { g1_i1 }\end{array}$ & $\begin{array}{l}\text { growth differentiation } \\
\text { factor } 7\end{array}$ & & \\
\hline $\begin{array}{l}\text { TRINITY_DN33837_c0_ } \\
\text { g3_i1 }\end{array}$ & $\begin{array}{l}\text { TNF receptor-associated } \\
\text { factor } 5 \text {-like }\end{array}$ & $\begin{array}{l}\text { TRINITY_DN29790_c0_ } \\
\text { g3_i1 }\end{array}$ & $\begin{array}{l}\text { ubiquitin-60S ribosomal } \\
\text { L40 }\end{array}$ & & \\
\hline $\begin{array}{l}\text { TRINITY_DN34897_c0_ } \\
\text { g1_i1 }\end{array}$ & tolloid 2 & $\begin{array}{l}\text { TRINITY_DN35733_c0_ } \\
\text { g1_i1 }\end{array}$ & $\begin{array}{l}\text { probable E3 ubiquitin- } \\
\text { ligase partial }\end{array}$ & & \\
\hline $\begin{array}{l}\text { TRINITY_DN29790_c0_ } \\
\text { g3_i1 }\end{array}$ & $\begin{array}{l}\text { ubiquitin-60S ribosomal } \\
\text { L40 }\end{array}$ & $\begin{array}{l}\text { TRINITY_DN16075_c0_ } \\
\text { g1_i1 }\end{array}$ & bone morphogenetic 7 & & \\
\hline
\end{tabular}




\begin{tabular}{|l|l|l|l|l|l|}
\hline $\begin{array}{l}\text { TRINITY_DN28521_c0_ } \\
\text { g1_11 }\end{array}$ & $\begin{array}{l}\text { bone morphogenetic 6- } \\
\text { like }\end{array}$ & $\begin{array}{l}\text { TRINITY_DN27508_c0_ } \\
\text { g1_i1 }\end{array}$ & $\begin{array}{l}\text { growth differentiation } \\
\text { factor 8-like }\end{array}$ & \\
\hline $\begin{array}{l}\text { TRINITY_DN8356_c0_g } \\
\text { 2_i1 }\end{array}$ & $\begin{array}{l}\text { ubiquitin-conjugating } \\
\text { enzyme E2 K-like }\end{array}$ & $\begin{array}{l}\text { TRINITY_DN27456_c0_ } \\
\text { g1_i1 }\end{array}$ & tolloid 1 & & \\
\hline $\begin{array}{l}\text { TRINITY_DN16075_c0_ } \\
\text { g1_i1 }\end{array}$ & bone morphogenetic 7 & $\begin{array}{l}\text { TRINITY_DN34419_c1_ } \\
\text { g1_i1 }\end{array}$ & pinhead precursor & & \\
\hline $\begin{array}{l}\text { TRINITY_DN27508_c0_ } \\
\text { g1_11 }\end{array}$ & $\begin{array}{l}\text { growth differentiation } \\
\text { factor 8-like }\end{array}$ & $\begin{array}{l}\text { TRINITY_DN30012_c0_ } \\
\text { g1_i1 }\end{array}$ & $\begin{array}{l}\text { oxidative stress-induced } \\
\text { growth inhibitor 2-like }\end{array}$ & & \\
\hline $\begin{array}{l}\text { TRINITY_DN31167_c0_ } \\
\text { g1_i2 }\end{array}$ & $\begin{array}{l}\text { segment polarity } \\
\text { dishevelled homolog }\end{array}$ & $\begin{array}{l}\text { TRINITY_DN32735_c0_ } \\
\text { g1_i2 }\end{array}$ & G- coupled receptor 161-like & & \\
\hline $\begin{array}{l}\text { TRINITY_DN46355_c0_ } \\
\text { g1_11 }\end{array}$ & hedgehog precursor \\
\hline $\begin{array}{l}\text { TRINITY_DN34419_c1_ } \\
\text { g1_i1 }\end{array}$ & pinhead precursor & & & & \\
\hline $\begin{array}{l}\text { TRINITY_DN19433_c0_ } \\
\text { g1_i1 }\end{array}$ & $\begin{array}{l}\text { MULTISPECIES: cold- } \\
\text { shock }\end{array}$ & & & & \\
\hline $\begin{array}{l}\text { TRINITY_DN32811_c0_ } \\
\text { g1_11 }\end{array}$ & glutaredoxin & & & & \\
\hline $\begin{array}{l}\text { TRINITY_DN32811_c0_ } \\
\text { g1_i3 }\end{array}$ & thioredoxin & & & & \\
\hline $\begin{array}{l}\text { TRINITY_DN33675_c0_ } \\
\text { g2_11 }\end{array}$ & $\begin{array}{l}\text { alkyl hydroperoxide } \\
\text { reductase }\end{array}$ & & & & \\
\hline
\end{tabular}

